ارزيابى اثرات شوكى متغيرهاى تراز يرداختها بر متغيرهاى كلان اقتصادى

منتخب با استفاده از الكوى خودر كرسيون بردارى عامل افزوده توده (FAVAR)

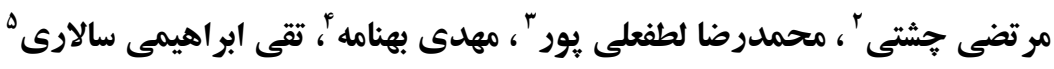

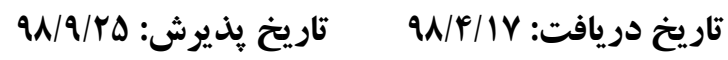

جكيله

تراز برداخت هاى بين المللى يكى از رايجترين معيارهاى سنجش و اندازه خيرى جريان مبادلات

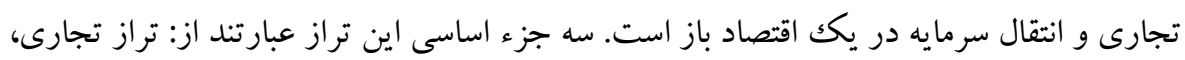

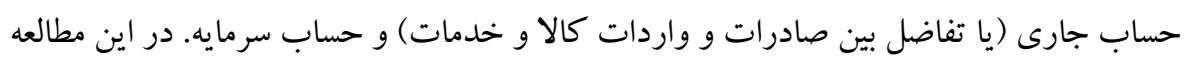
جهت ارزيابى اثرات شوككهاى تراز يرداختها بر متغيرهاى كلان اقتصادى در اقتصاد ايران از ونان

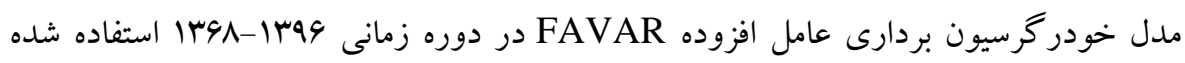

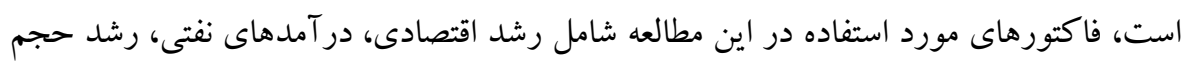

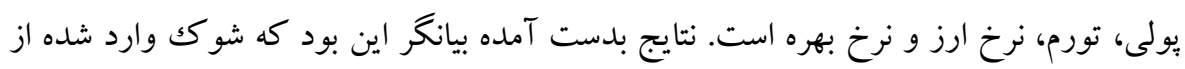

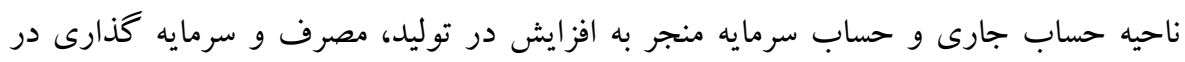

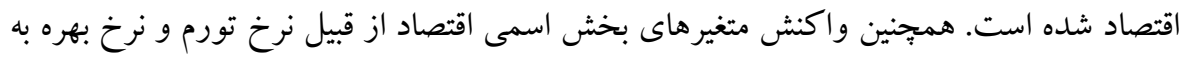

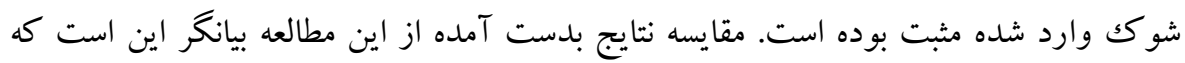

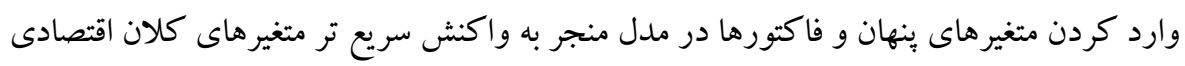

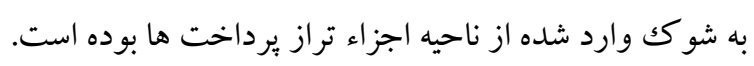

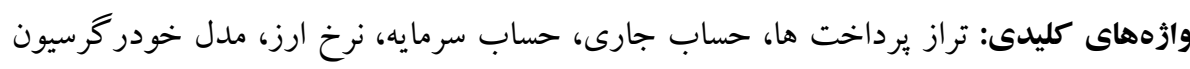

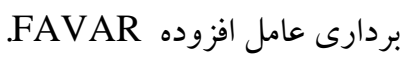

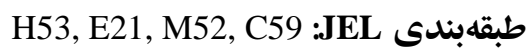

\footnotetext{
I. اين مقاله مستخرج از رساله دكترى مر تضى جشتى در دانشخاه فردوسى مشهد است.

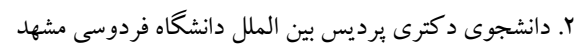
Email:cmorteza33@gmail.com

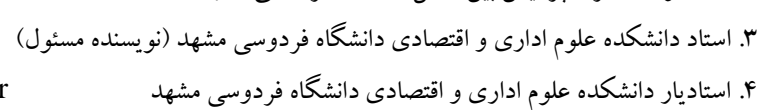
Email:lotfalipour@um.ac.ir Email:mehdi_behnamei@um.ac.ir Email:ebrahime@um.ac.ir

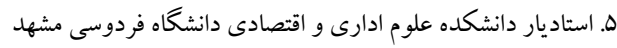




\section{Q $\square$ V.}

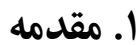

تراز برداختها يكى از بزركترين معيارهاى سنجش و اندازهگيرى جريان مبادلات

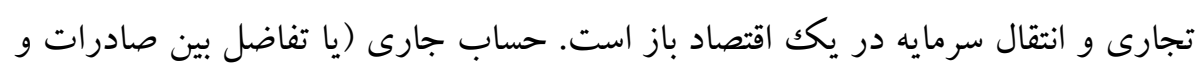

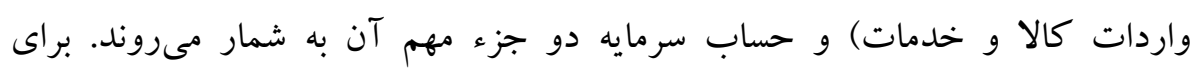
كشورهاى در حال توسعه وضعيت تراز حساب جارى و حساب سرمايه از جمله مهمترين

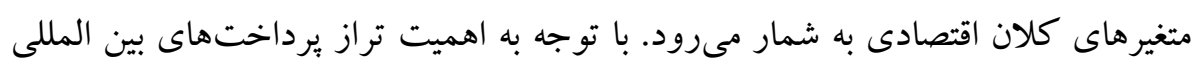

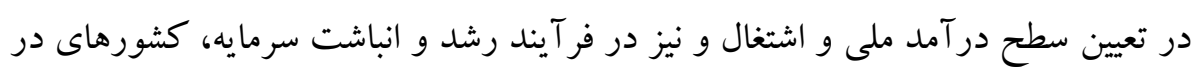

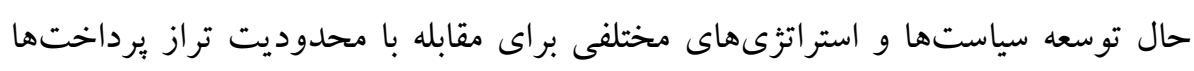

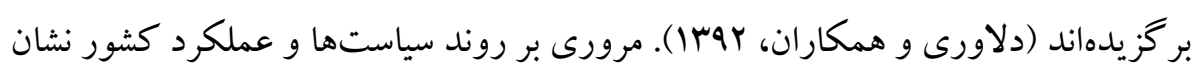

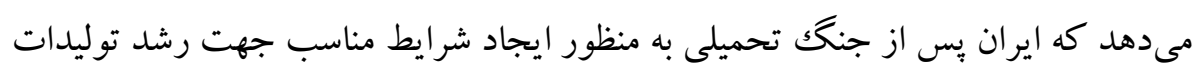

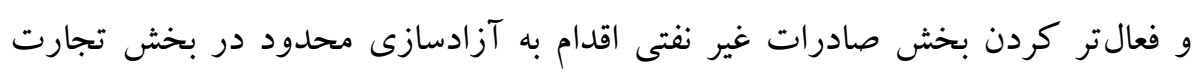

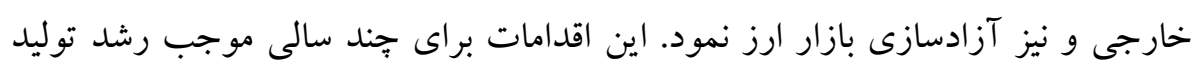

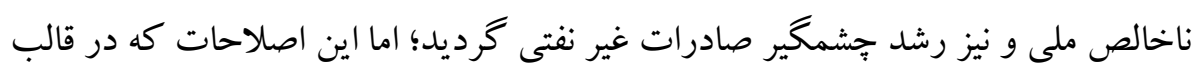

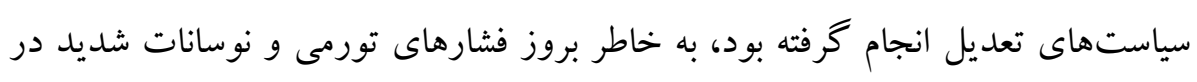

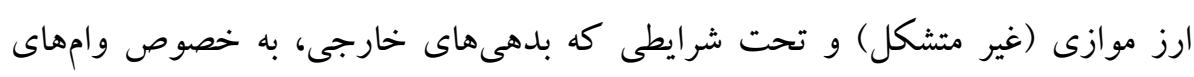
كوتاه مدت، براى مدتى محدود وضعيت دشوار ارزى را در كشور ايجاد نموده بود، معلق

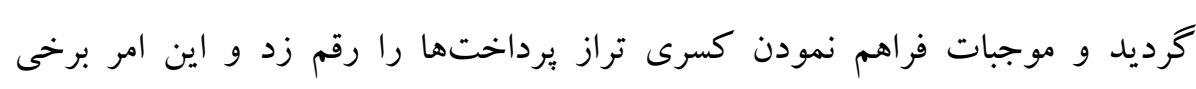

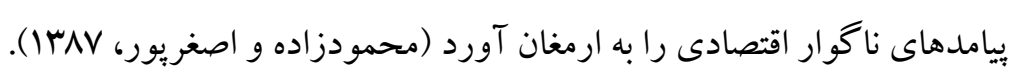

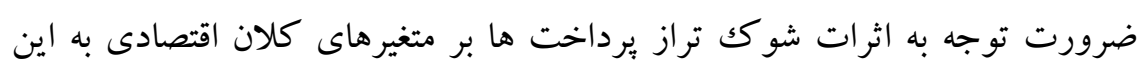

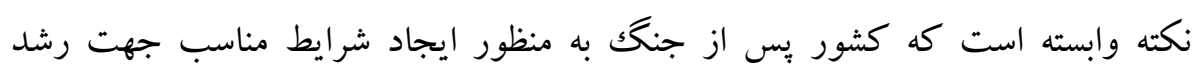

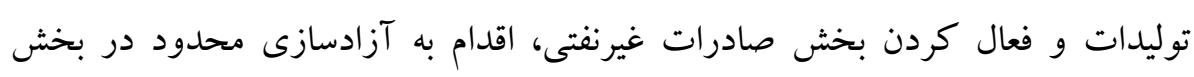

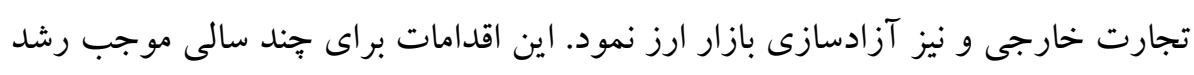

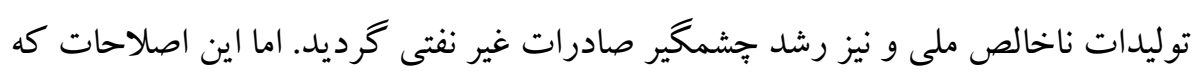

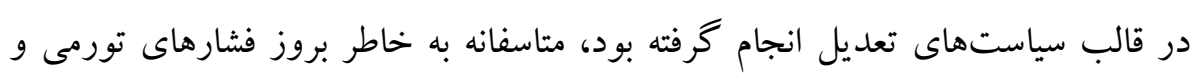


نوسانات شديد در بازار ارز غير متشكل و تحت شرايطى كه بدهى هاى خارجى، به ويزه وامهاى كوتاه مدت، براى ملتى محدود وضعيت دشوار ارزى را در كشور ايجاد نموده

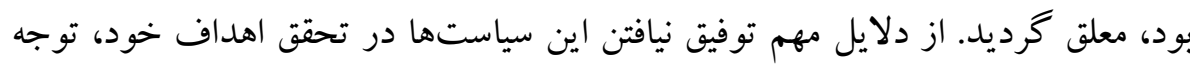
نا كافى به انضباط مالى و يولى و عدم وجود يكك فضاى مناسب كلان اقتصادى بود. در ادبيات اقتصادى تأكيد شده كه ارتباط بين تجارت بين الملل و رشد متقابل است.

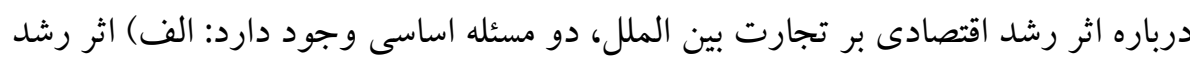

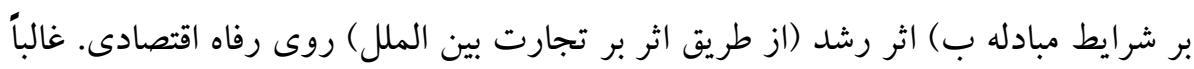
براى بررسى نظرى آثار رشد اقتصادى بر تجارت بين الملل فرض مى شود كه هر كشور

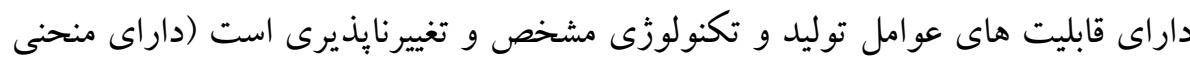
امكانات توليد معين است) و همجنين سليقه هاى مردم مشخص و غير قابل تغيير است (لذا،

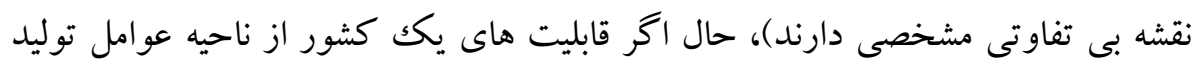
تغيير كند و يا تكنولوزى بهبود يابد، اين تغييرات سبب مى شود كه منحنى امكانات توليد كشور تغيير مكان بيدا كند. تغيير در سلايق مردم يكك كشور هم نقشه بى تفاوتى جديدى

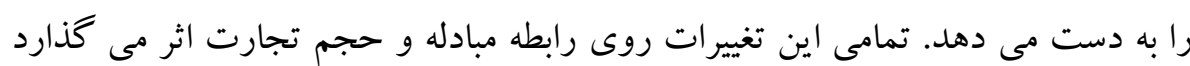

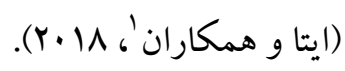
مساله اصلى تحقيق حاضر به اين شرح است كه در زمينه ارتباط بين متغيرهاى كلان

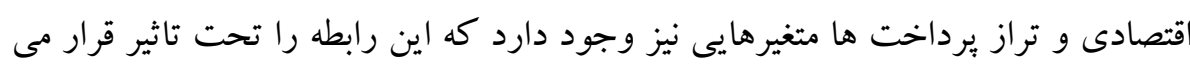
دهد. متغيرهاى ينهان، متغيرهايى هستند كه به صورت مستقيم قابل مشاهده نيستند اما از ميان متغيرهاى ديخر كه قابل مشاهده هستند توسط يكك الكوى رياضى استنباط مى شوند.

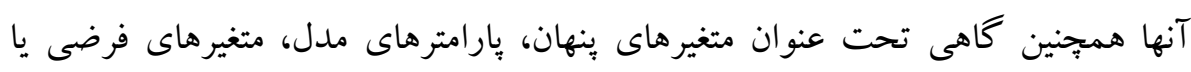

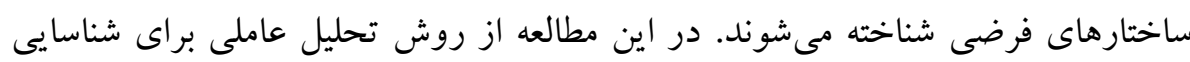
متغيرهاى ينهان استفاده مى شود كه با تركيب متغيرهاى تراز يرداخت ها شامل حساب

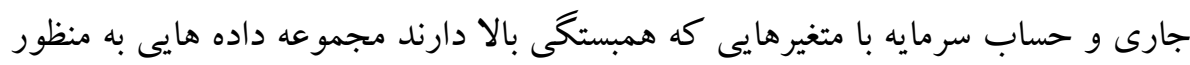


تخمين عوامل ينهان اقتصاد ايران مورد استفاده قرار مى گيرند. آنها عبارتند از گروه هاى

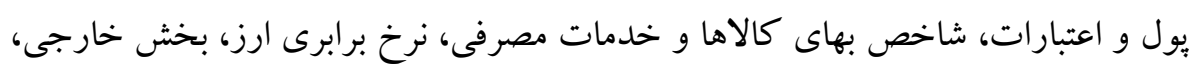

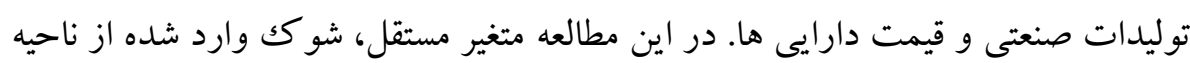

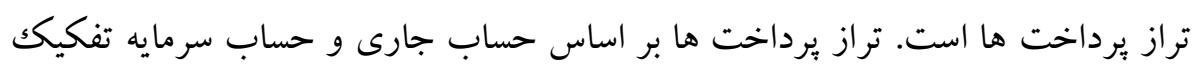

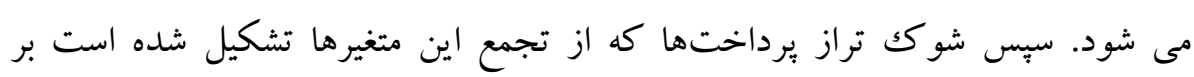

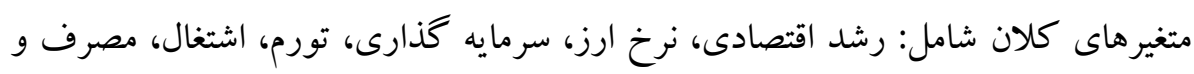
كسرى بودجه بررسى مى شود و از طرفى شوكى متغيرهاى كلان اقتصادى از جمله توليد،

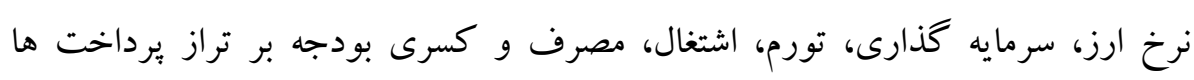
بررسى مى شود. مقاله حاضر در ينج بخش تنظيم شده است، در بخش دوم مبانى ادبيات تحقيق مورد

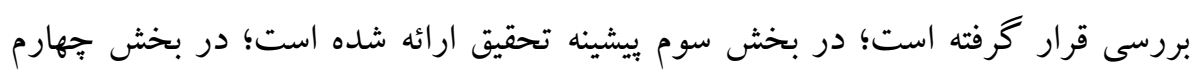

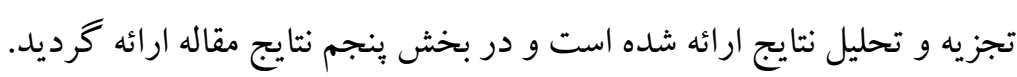

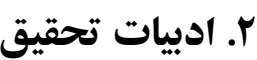

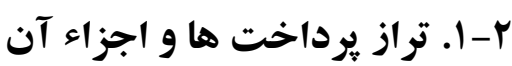

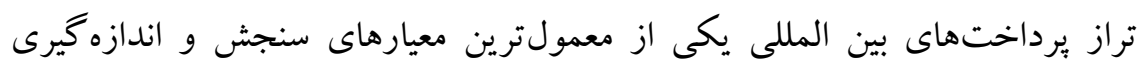
جريان مبادلات تجارى و انتقال سرمايه در يكك اقتصاد باز است. سه جزء اساسى استى اين تراز

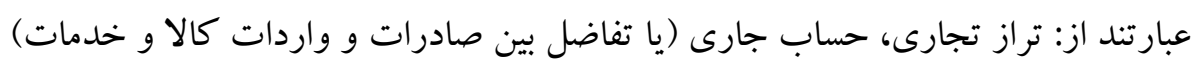

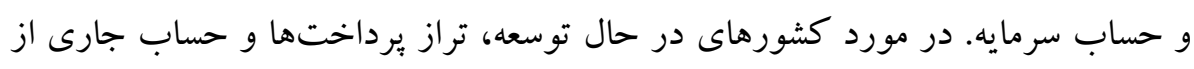
مهمترين متغيرهاى كلان و از محدوديتهاى استر اتزيكك اقتصاد كلان هستند. عدم تعادل در تراز يرداختهاى داخلى، مانند، كسرى بودجه دولت، حداقل در كوتاه مدت قابل مهرديل

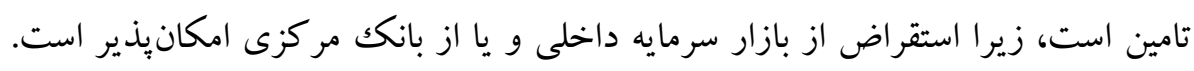

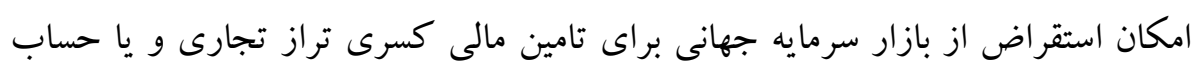

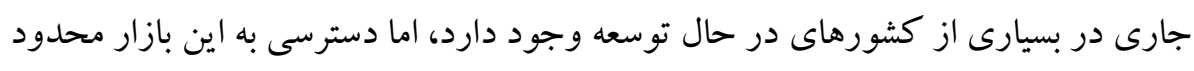

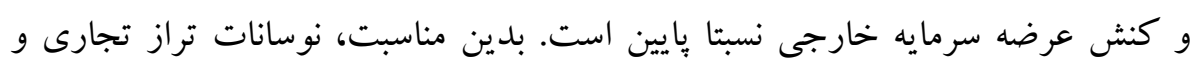


حساب جارى بر سطح و تركيب توليد ناخالص ملى تاثيرات مهمى دارد. شوككهاى ارزى منفى مربوط به تراز برداخت ها در كشورهاى نيمه صنعتى با محدوديت دسترسى به به بازار

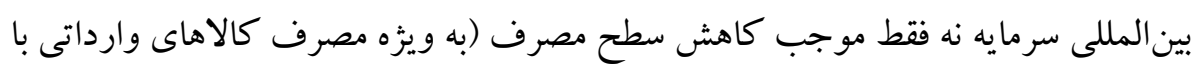

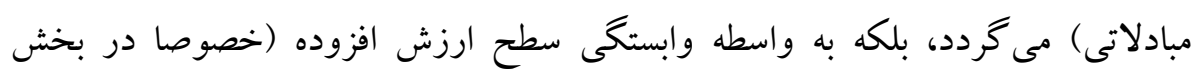

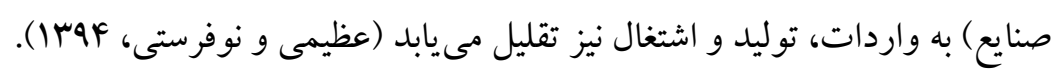

\section{r-r r عوامل اثر Fذار بر تراز يرداخت ها}

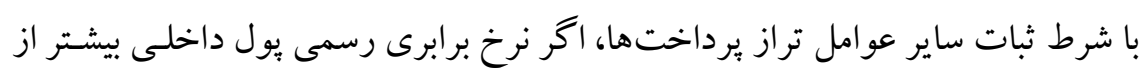

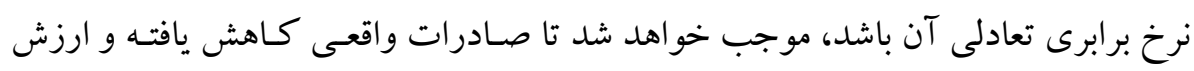

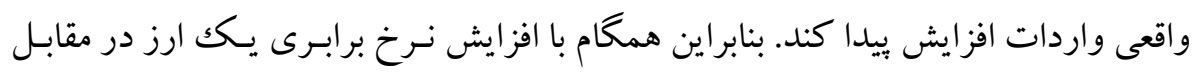

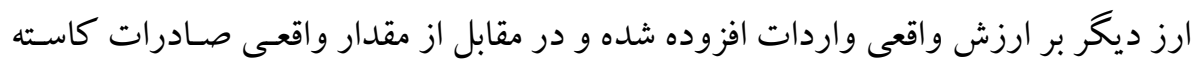

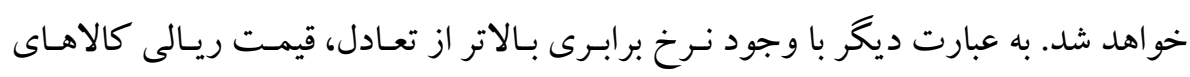

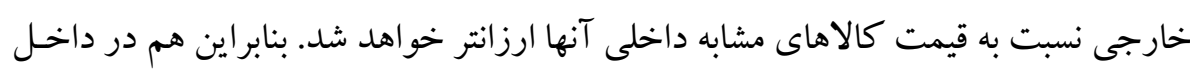
كشور و هم در خارج، تقاضا براى كالاهاى خارجى جانشين كالاهاى داخلى مسى شـود. بـــ

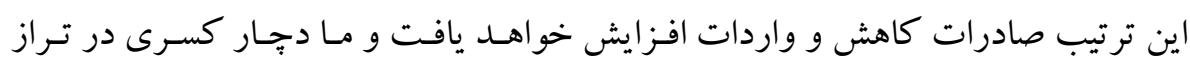

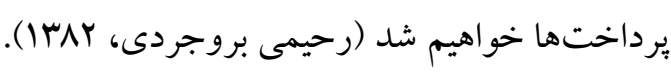

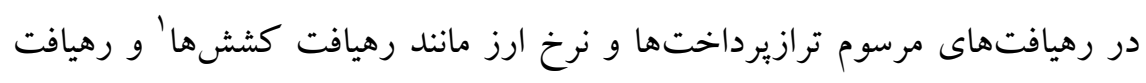

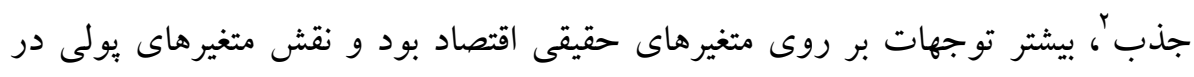

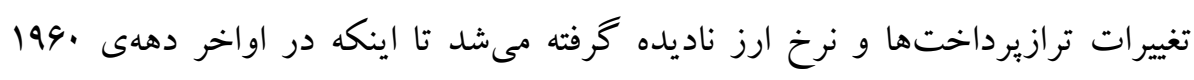
ديد كاه جديدى كه بعدها تحت عنوان رهيافت بولى ترازيرداخت ها مرسوم شد در ادبيات

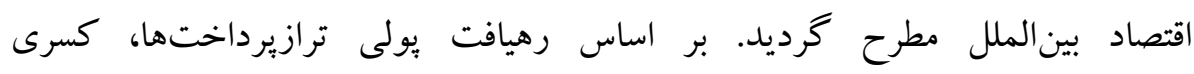

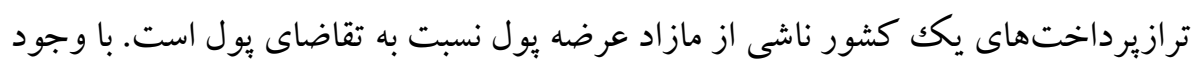

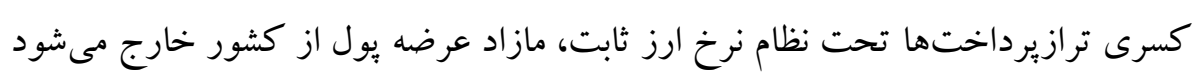




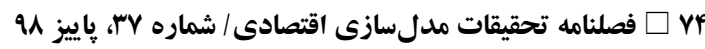

و يا از سوى ديخر مازاد ترازيرداختها ناشى از مازاد تقاضاى يول بوده كه تحت نظام نرخ

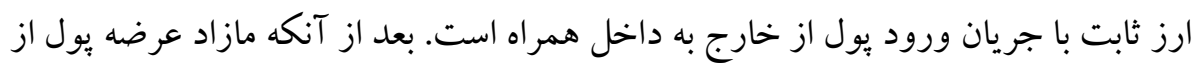

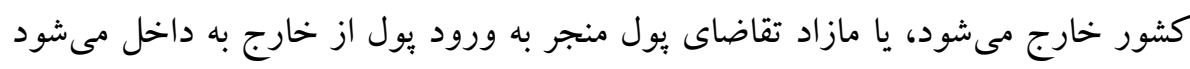

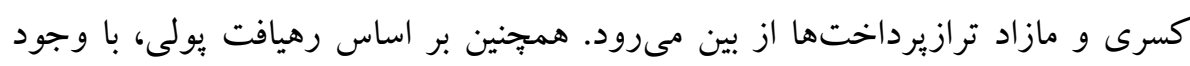

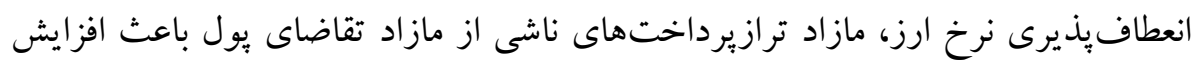

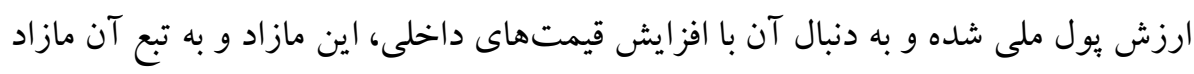
ترازيرداختها از بين مىرود و بر عكس اين حالت وقتى كه كسرى ترازيرداختها و و مازاد عرضه يول وجود دارد، رخ مىدهد. به طور كلى بر اساس رهيافت يولى كاهش ارزش يول

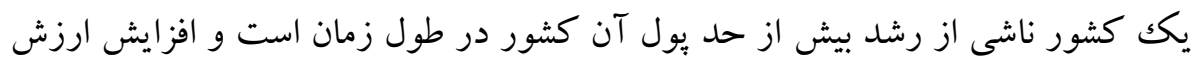

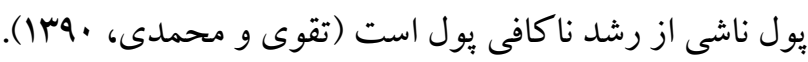

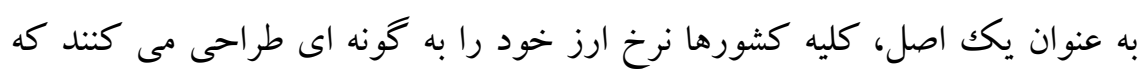
سيب حفظ قدرت رقابتى خارجى آنان شود و از اين طريق موازنه بِايدارى را براى يرداختهاى خارجى به دست آورند. از طرفى يكى از دلايل عمده تضعيف قدرت رقابت

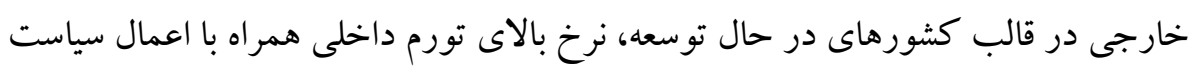

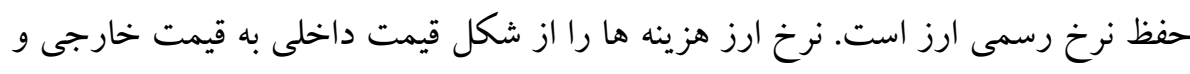

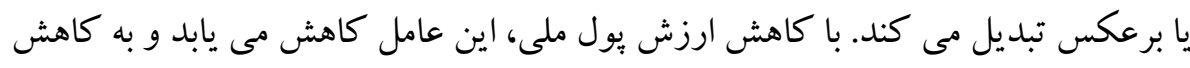

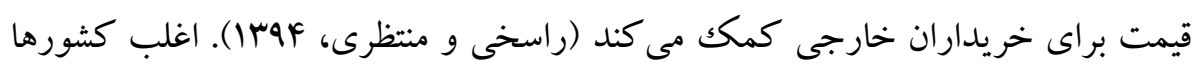
تلاش مى كنند تا به منظور كسب توان رقابت هزينه هاى بالاى خود را با كاهش ارزش بـ بول

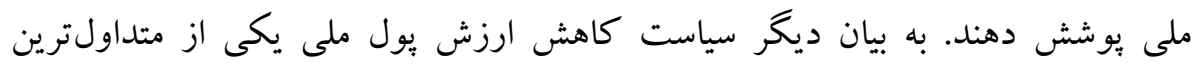

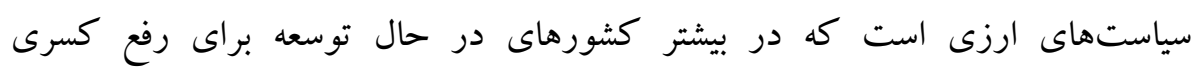

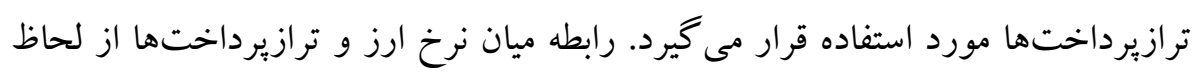

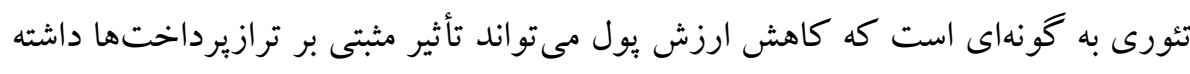

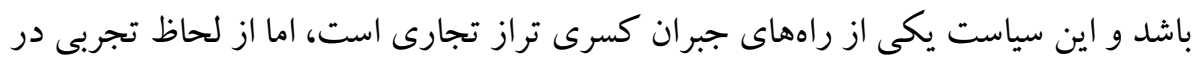

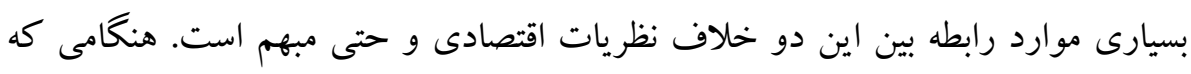


يول يكك كشور كاهش ارزش مى بايد از طريق دو مجرا (كانال) بر ترازيرداختها اثر مى كذارد (لطفعلى بور و بازر گان، هوسا).

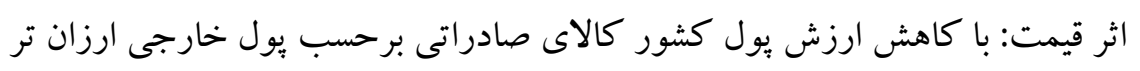

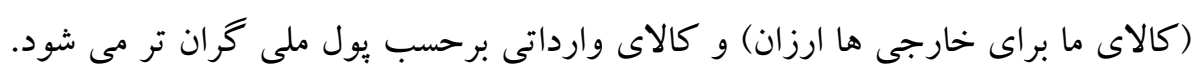
لذا اثر قيمت موجب بالاتر شدن حساب جارى كشور مورد نظر مى شى شوند.

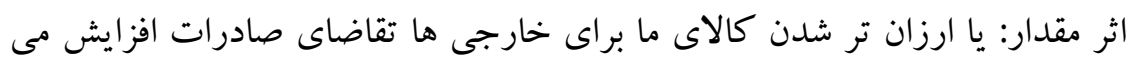
يابد و با گران تر شدن كالاهاى وارداتى حجم واردات كمتر و در نتيجه اثر مقدار موجب

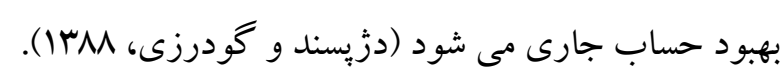

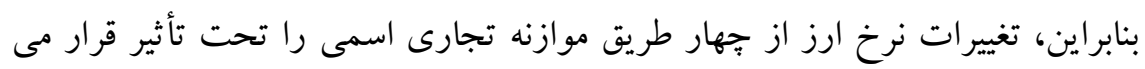

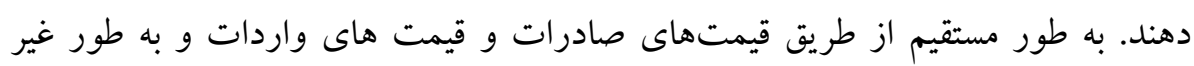
مستقيم از طريق عكس العمل حجم صادرات و واردات نسبت به تغيير قيمتهاى نسبى. كشورها معمولا جهت تعديل و تصحيح كسرى تراز يرداخت از سياست هاى افزايش نرخ

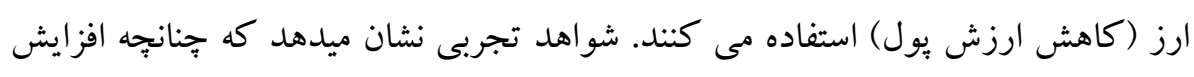

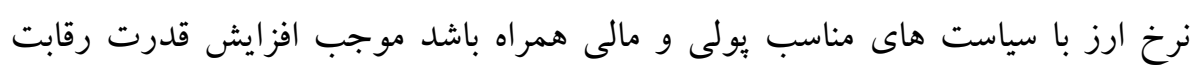

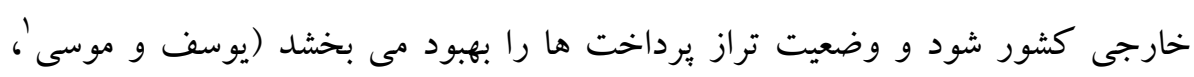
. $(Y \cdot) \wedge$

درمورد اثر گذارى شو كك تراز برداخت ها بر متغيرهاى كلان اقتصادى مى توان جنين

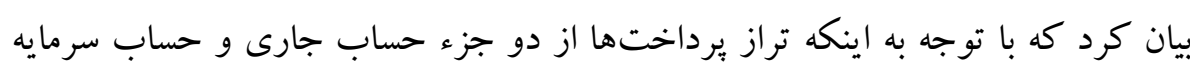

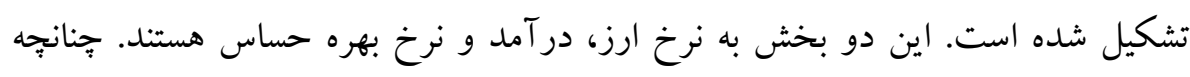

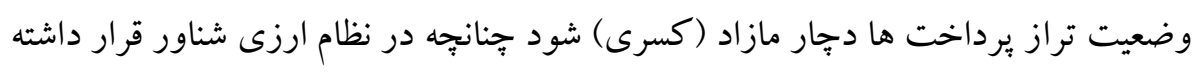
باشيم منجر به كاهش (افزايش) در نرخ ارز خواهد شد. اين تغييرات منجر به كاهش ماتش

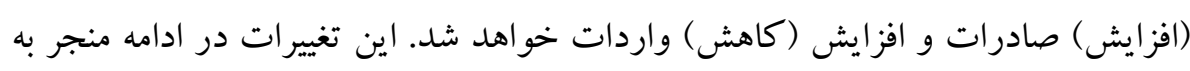
كاهش (افزايش) حساب جارى مى شود. اين مجموعه تغييرات در نهايت منجر به كاهش واردات 
(افزايش) در نرخ بهره و كاهش (افزايش) در توليد مى شود. حال جنانجه در نظام ارزى

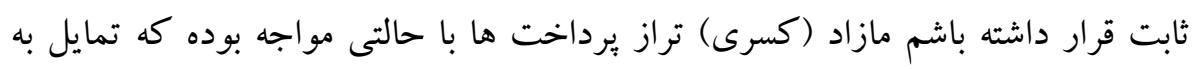

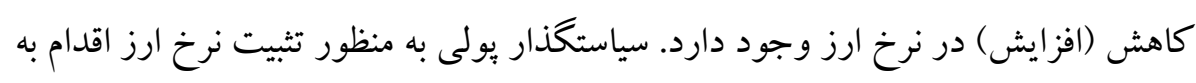

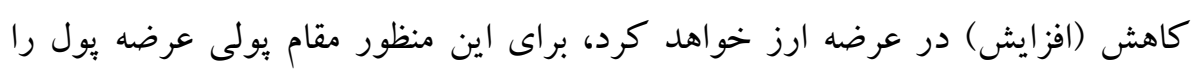

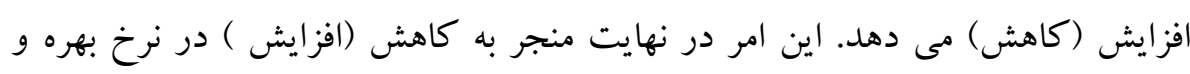

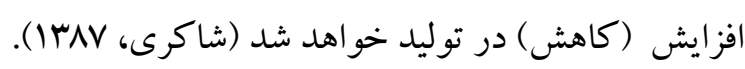

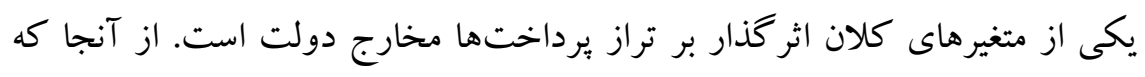
دولت نقش مهمى را در فر آيند عرضه يول و فعاليتهاى اقتصادى بازى مى كند، تغييرات

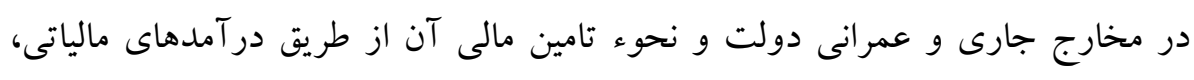

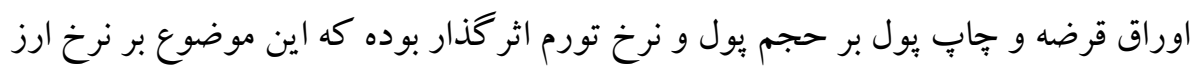

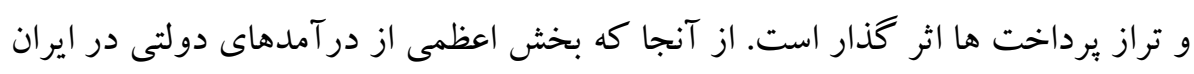
از دو منبع درآمدهاى مالياتى و درآمدهاى نفتى حاصل مىشود، اين متغيرها از طريق كسرى بودجه دولت بر تغييرات نرخ ارز و تورم و به تبع آن بر تراز برداخت ها اثر كذار

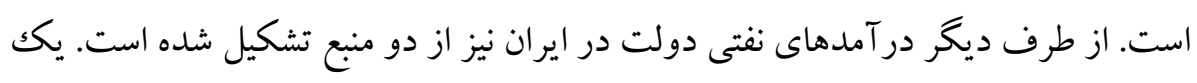

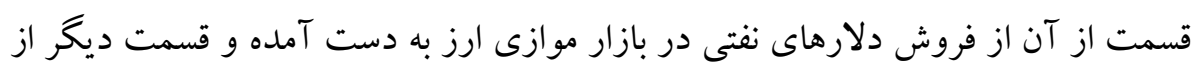

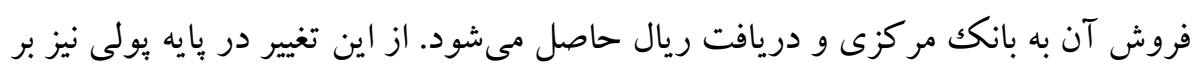

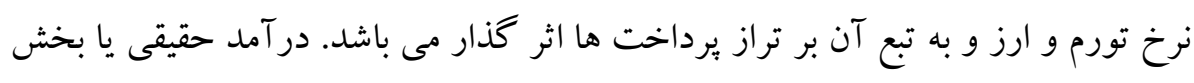

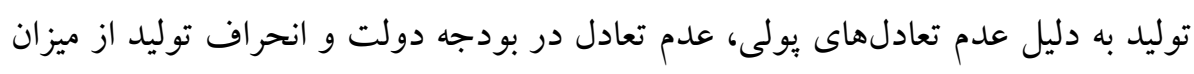

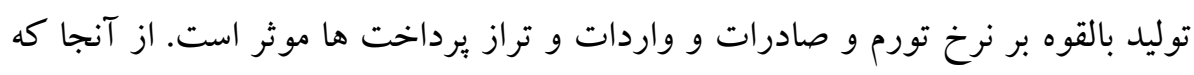

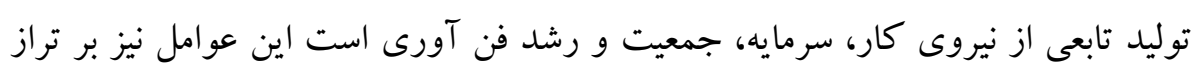

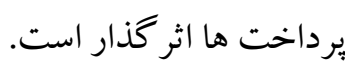
اقتصادهاى نوظهور و در حال توسعه به طور خاص نسبت به شوكى هاى خارجى آنى آسيب يذير هستند. اين آسيب يذيرى از طريق كانالهايى مانند كانال تجارى يا مالى رخ

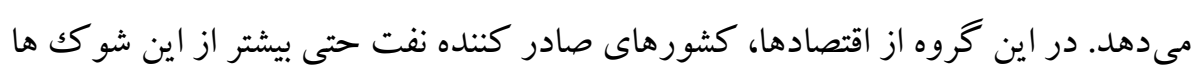


نيز در معرض خطر هستند. در واقع، اقتصادهاى متكى به صادرات نفت به شدت به در آمد

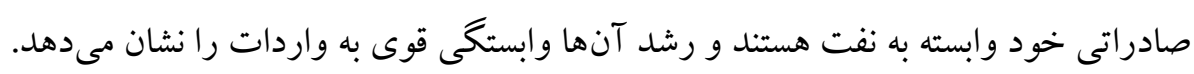

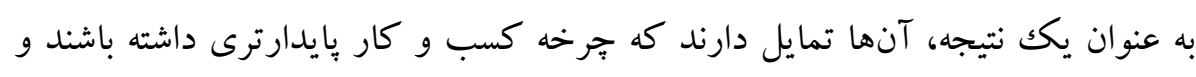

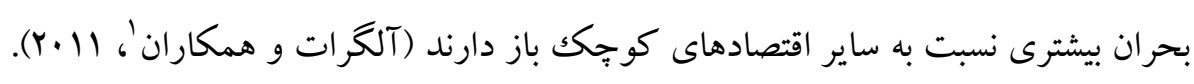

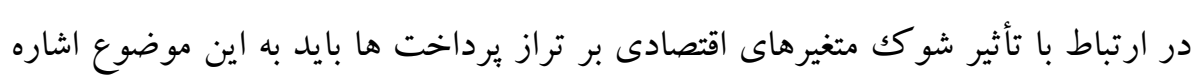

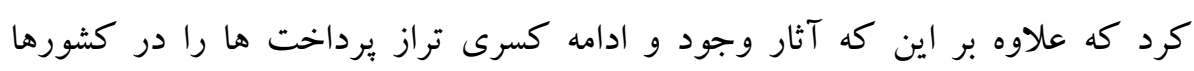
مشخص مى كند، نحوه تدوين و اتخاذ سياست هاى مناسب كلان اقتصادى را نيز براى نيل به تعادل در بخش خارجى و كاهش كسرى تراز برداخت ها روشن مى نمايد. مشكلات

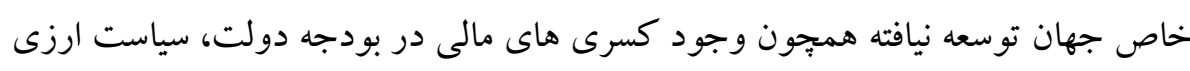

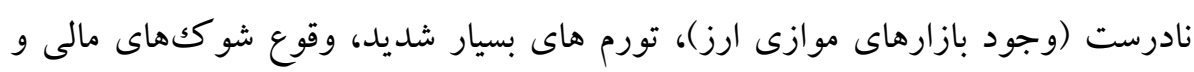

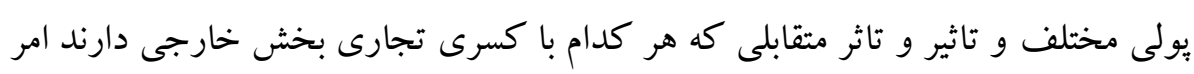
بر بسى را مهمتر ساخته است.

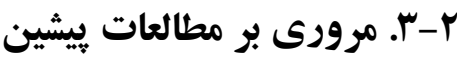

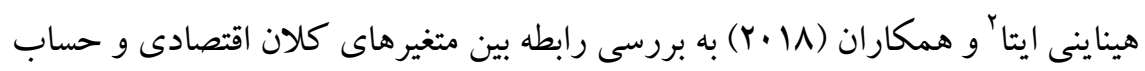

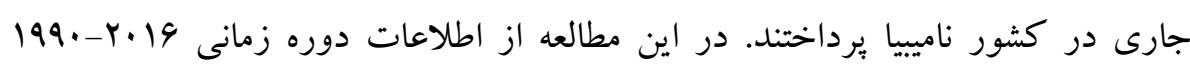
استفاده شده است. در راستاى تحليل نتايج از روش خودهمبسته با وقفههاى توزيعى دري

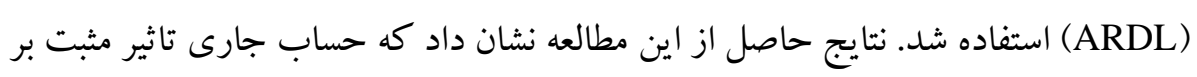

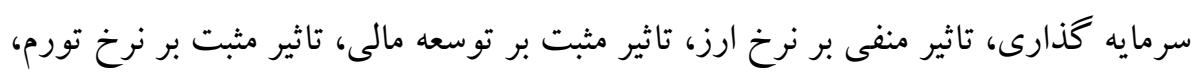
نرخ بهره و توليد ناخالص داخلى داشته است.

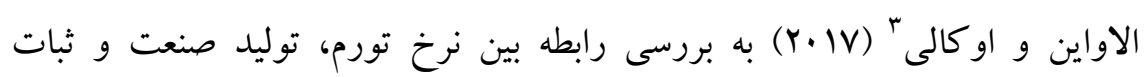

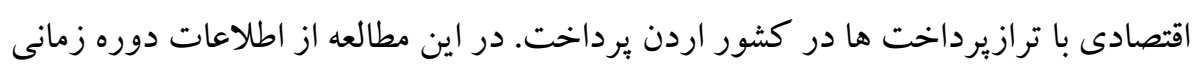

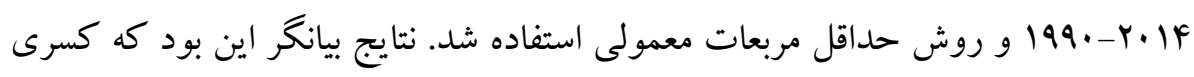


تراز يرداخت ها منجر به كاهش در تورم مى شود. همجِين نتايج بيانكر اين بود كه كسرى

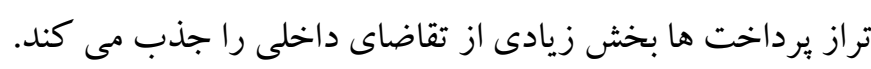

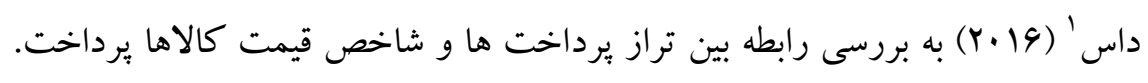

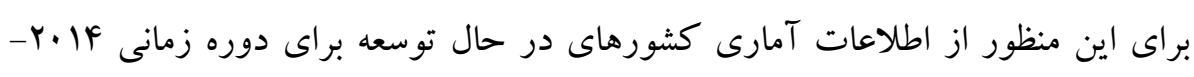
....

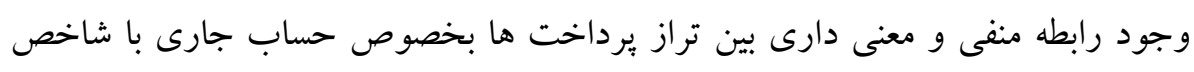

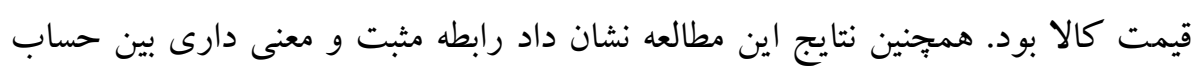
جارى و توليد ناخالص داخلى وجود داشته است.

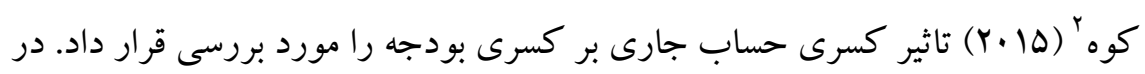

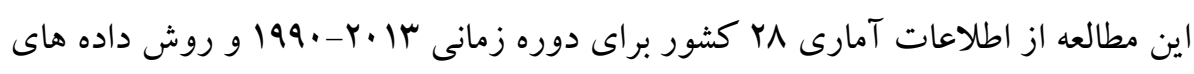

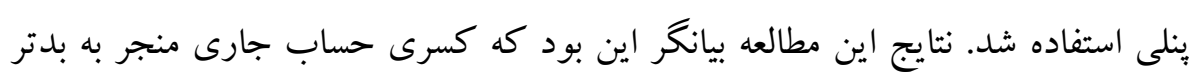
شدن وضعيت كسرى بودجه دولت مى شود.

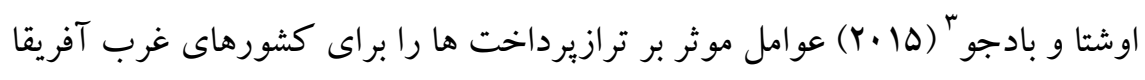

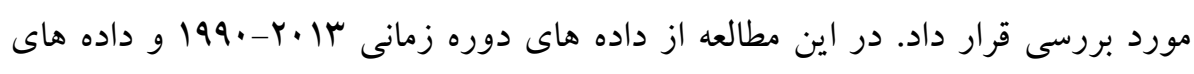

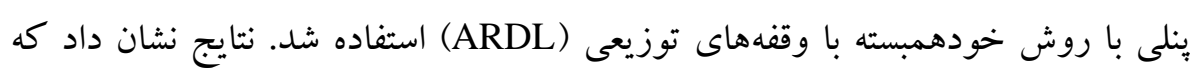

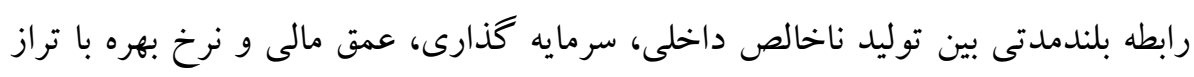
برداخت ها در اين كشورها وجود دارد.

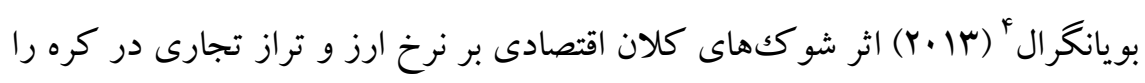
با استفاده از الكو خودتصحيح بردارى ساختارى برداخته است. بر اساس نتايج بدست آمداه

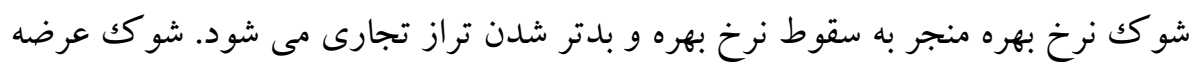

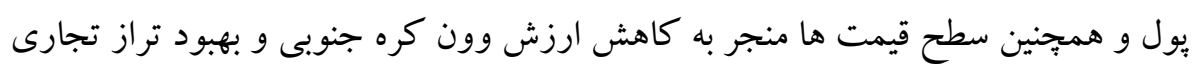

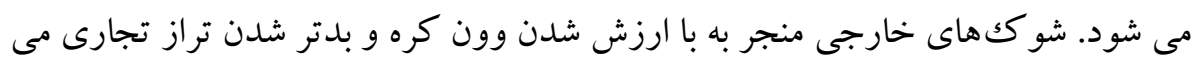

1. Das

2. Kueh

3. Oshota and Badejo

4. Buyangeral 
شود. به علاوه شوكك كاهش نرخ ارز وون كره را مجبور به بهبود تراز تجارى مى نمايد. نتايج نشان مىدهد جهش نرخ ارز خود باعث شوككهاى نرخ ارز است و شوكى نرخ ارز

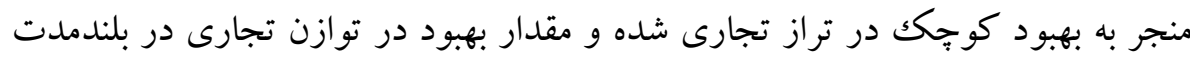

$$
\text { بزرك تر مىشود. }
$$

قادرى و همكاران (هوسا) تأثير تكانه كسرى بودجه بر كسرى حساب جارى در

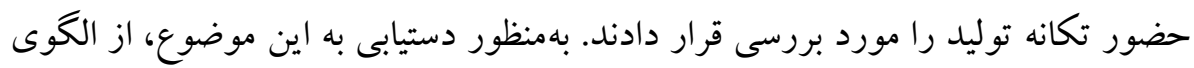

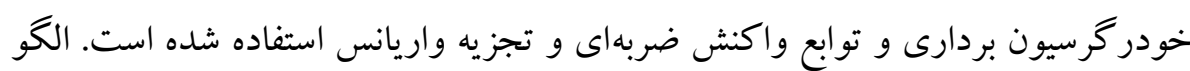

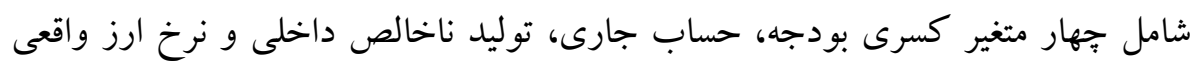
است. نتايج اين مقاله، نشاندهنده رابطه منفى بين كسرى بودجه و و كسرى حساب حساب جارى

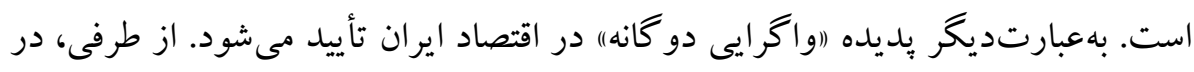

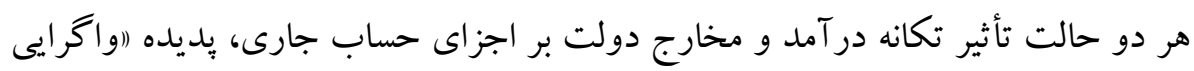
دو گانه)) بهصورت ضعيف، تأييد شده است.

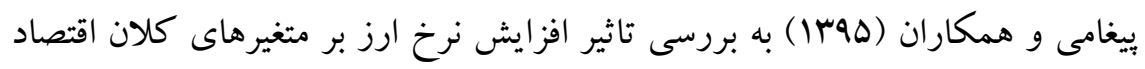

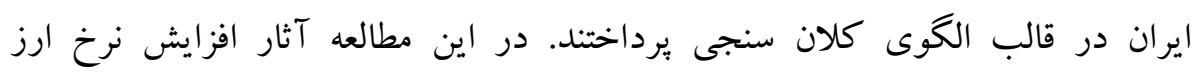
برمتغيرهاى كليدى اقتصاد، در جارجوب يكك مدل كلان سنجى معادلات همزمان،

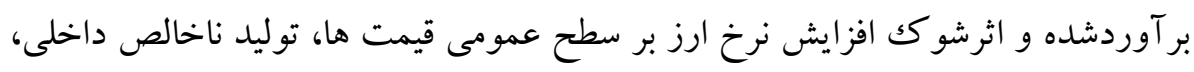

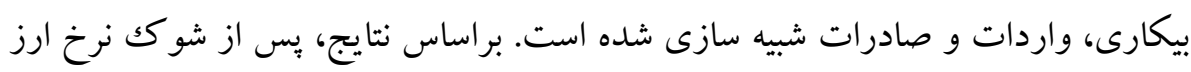

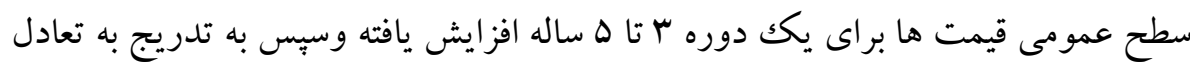

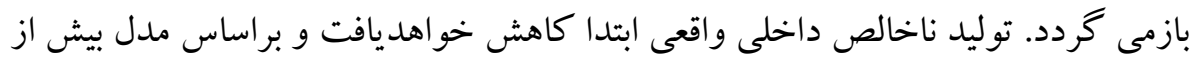

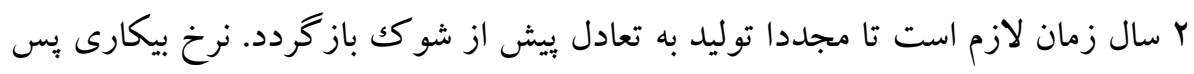

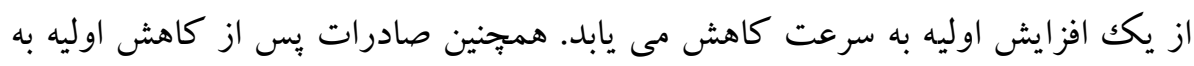
سرعت افزايش مى يابد كه البته، اين دوره بين يكك تاسه سال به طول مى انجامد.

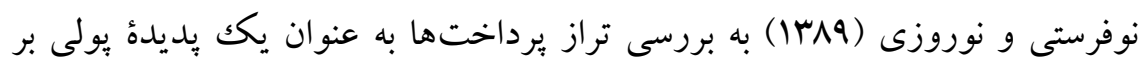

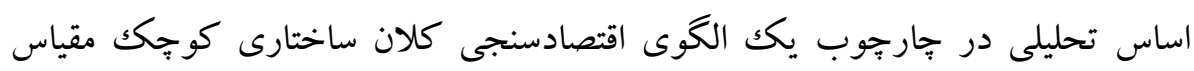




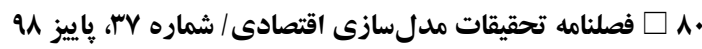

يرداختند. در اين مطالعه معادلات تصريح شده با استفاده از دادههاى سرى زمانى سالهاى

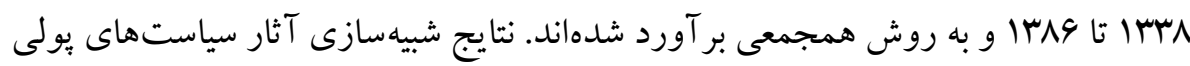
و ارزى توسط الكو حاكى از آن است كه · 1٪ افزايش در نرخ سبردهُ قانونى، سطح عمومى قيمتها را در سالهاى بس از اجراى اين سياست به طور متوسط حدود ه/11\%

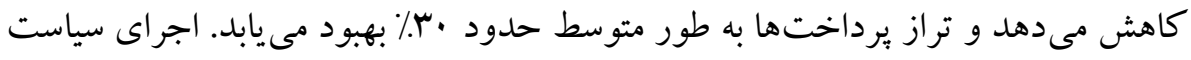

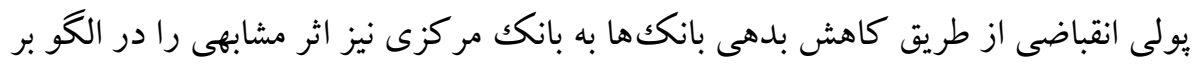

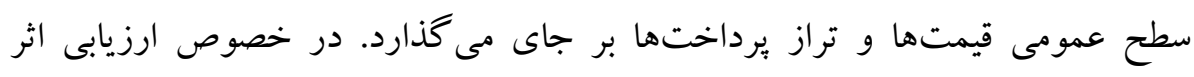

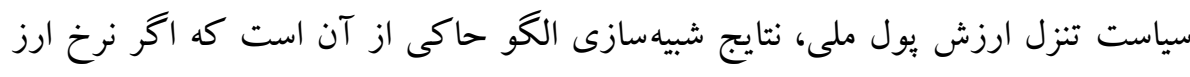

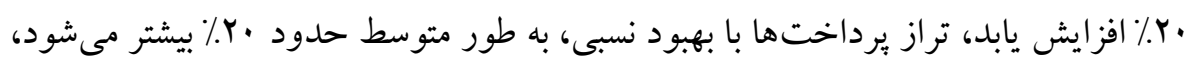
اما سطح عمومى قيمتها در سالهاى بس از اجراى اين سياست به طور متوسط حدود V.

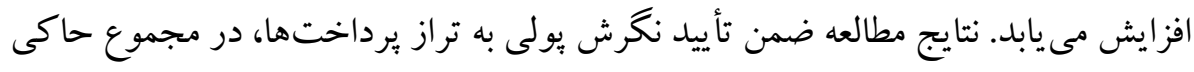

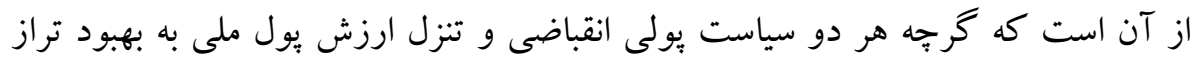

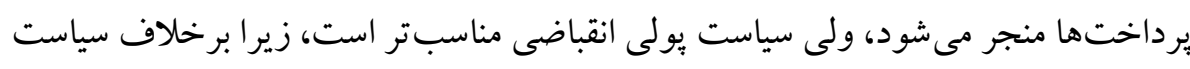
تنزل ارزش يول ملى، سطح عمومى قيمتها را كاهش مى دهد.

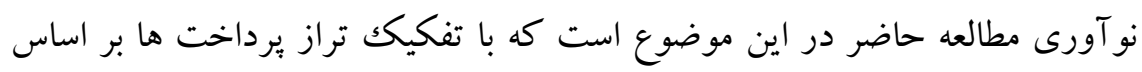
حساب جارى و حساب سرمايه اثرات شوك هر يكك از اين اجزاء بر متغيرهاى كلان

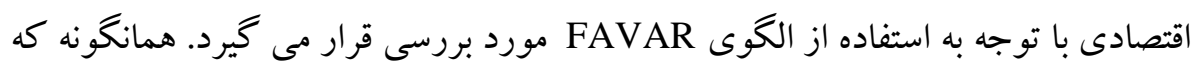
مشاهده مى شود در داخل كشور مطالعه اى به بررسى اثرات شوكك هاى تراز يرداخت ها و

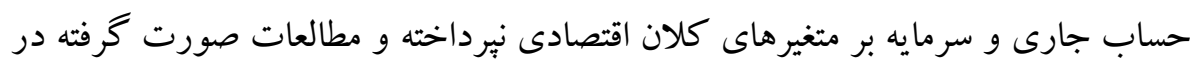
حوزه شوك ارزى و يا تاثير متغيرهاى اقتصادى بر حساب جارى بوده است متغيرهاى حساب جارى و حساب سرمايه تحت تاثير گروهى از متغيرها به عنوان متغيرهاى ينهان بوده و در اين مطالعه شامل شاخص قيمت مصرف كننده، توليدكننده، شاخص قيمت

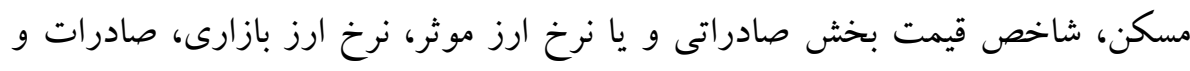
واردات كالاها و خدمات، ورود و خروج سرمايه و نرخ بهره است. 


\section{r. مدل تحقيق و روش بر آورد}

در حالت كلى با توجه به اينكه مدل هاى VAR به طور كستردهاى بود براى تجزيه و

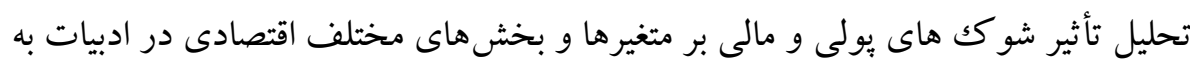

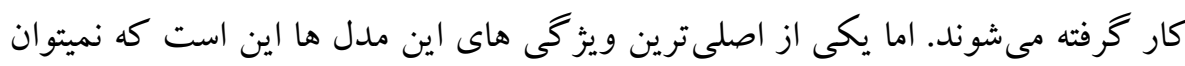

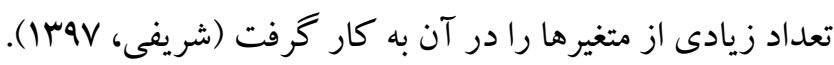

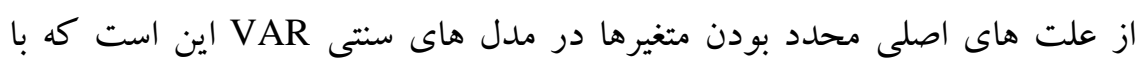

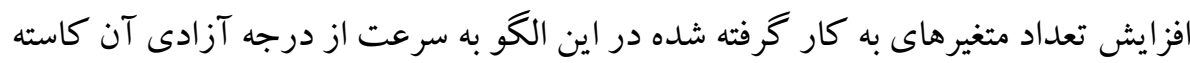
ميشود، زيرا در هر معادله، متغير وابسته بر روى وقفه هاى خودش و وقفه هاى ساير متغيرها

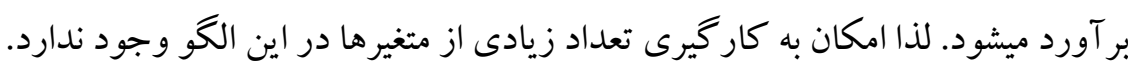

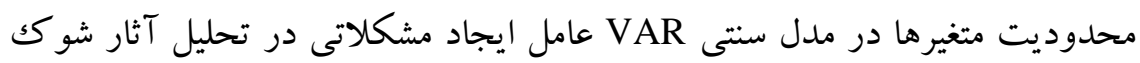

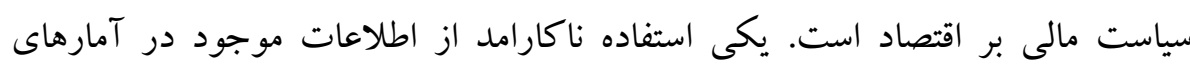

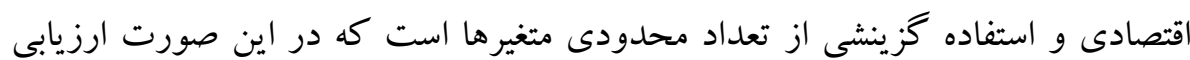

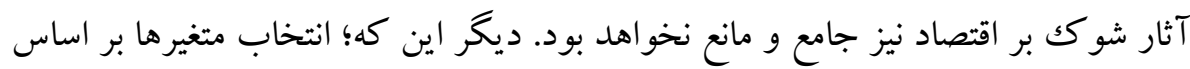
سليقه و گزينش محققان صورت ميخيرد. با ملاحظه اين مشكلات، اخيرا توجه زيادى به مدلهايى معطوف شده است كه ساختار

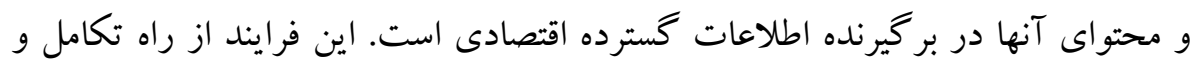
تو سعه مدل هاى سنتى VAR و با استفاده از يك يا جِند عامل، امكان بِذير شده است.

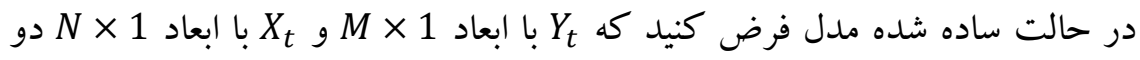

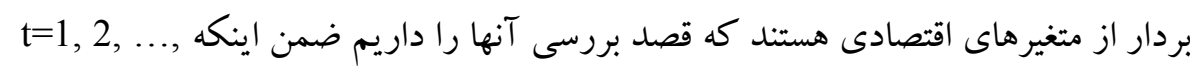

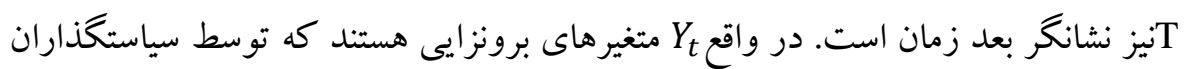

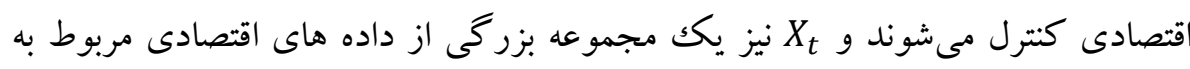
ساير متغيرهاى اقتصادى است. فرض مىشود كه برخى از عوامل يا نيروهاى بنيادى غيرقابل

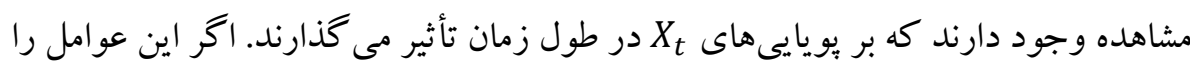


به صورت بردار F كه داراى ابعاد K×1 است نمايش داده شود، دراين صورت ميتوان

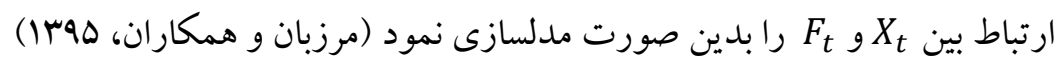

$$
X_{t}=\Lambda F_{t}+e_{t}
$$

كه در آن e بردار خطاها با ميانگين صفر مى باشد كه ممكن است اجزاى آن يك

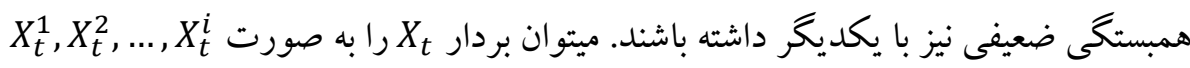

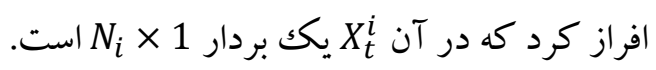

در اين صورت فرض مىشود كه هر يكك از بردارهاى

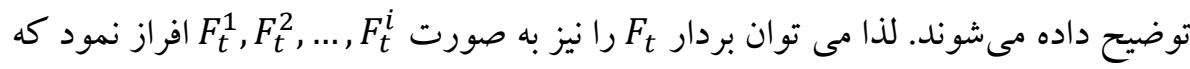

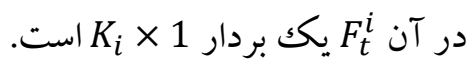

تحليل مولفه هاى اساسى(PC) ' و بررسى عوامل (FA) بُ روشهاى آمارى هستند كه

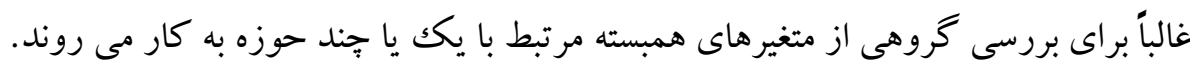

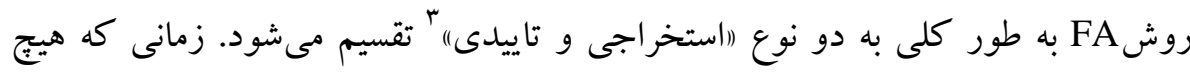

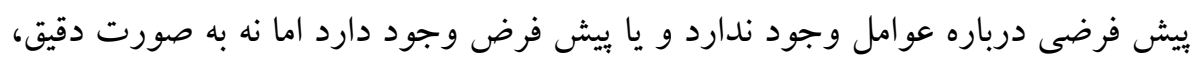

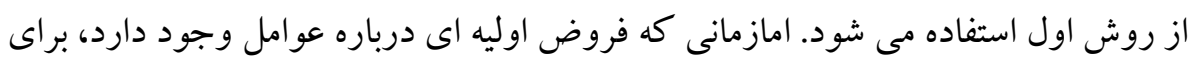
تاييد فروض از روش دوم استفاده مى شود. در ادبيات كاربردى روش تحليل عوامل، به

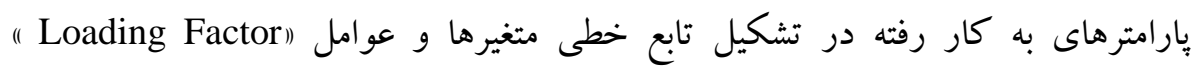
مى گويند. اشتراك بذيرى يُك متغير بخشى از واريانس آن است كه به به وسيله عوامل

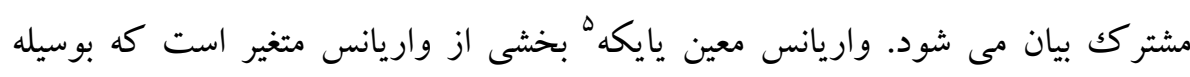

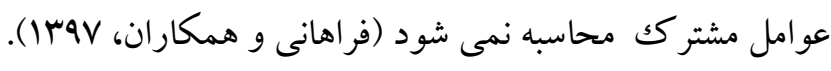
در صورتى كه Y متغير مشاهده شده و F و F $F_{1}$ دو عامل موثر باشند، بيان رياضى

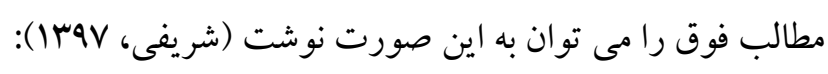

1. Principal Component Analysis

2. Factor Analysis

3. Exploratory and Confirmatory Factor Analysis

4. Communality

5. Specific Variance or Uniqueness 
$Y_{i}=\lambda_{i 1} F_{1}+\lambda_{i 2} F_{2}+(1) e_{i}$

$\operatorname{Var}\left(Y_{i}\right)=\lambda_{i 1}{ }^{2} \operatorname{Var}\left(F_{1}\right)+\lambda_{i 2}{ }^{2} \operatorname{Var}\left(F_{2}\right)+(1)^{2} \operatorname{Var}\left(e_{i}\right)$

$\lambda_{i 1}{ }^{2}+\lambda_{i 2}{ }^{2}+\partial_{i}{ }^{2}$

$\operatorname{Var}\left(Y_{i}\right)=\lambda_{i 1}{ }^{2}+\lambda_{i 2}{ }^{2}+\partial_{i}^{2}$

در صورتى كه n متغير و m عامل وجود داشته باشد، بيان ماتريسى موضوع به شرح زير مى

$X_{1}=\lambda_{11} F_{1}+\lambda_{12} F_{2}+\cdots+\lambda_{1 m} F_{m}+e_{1}$

$X_{2}=\lambda_{21} F_{1}+\lambda_{22} F_{2}+\cdots+\lambda_{2 m} F_{m}+e_{2}$

-...

$X_{n}=\lambda_{n 1} F_{1}+\lambda_{n 2} F_{2}+\cdots+\lambda_{m m} F_{m}+e_{n}$

$\left[\begin{array}{c}x_{1} \\ \vdots \\ \vdots \\ x_{n}\end{array}\right]_{n x^{1}}=\left[\begin{array}{cccc}\lambda_{11} & \ldots & \ldots & \lambda_{m} \\ \vdots & \ddots & & \vdots \\ \vdots & \ddots & & \vdots \\ \lambda_{n 1} & \ldots & \ldots & \lambda_{n m}\end{array}\right]_{n x m} \quad\left[\begin{array}{c}f_{1} \\ \vdots \\ f_{m}\end{array}\right]_{m x 1}+\left[\begin{array}{c}e_{1} \\ \vdots \\ \vdots \\ e_{n}\end{array}\right]_{n x 1}$

$X_{n \times 1}=A_{n \times m} F_{m \times 1}+e_{n \times 1}$

اخر عوامل به طور كامل متغيرهاى مشاهده شده را توضيح دهند، آنگاه مى توان نوشت:

$e_{1}=e_{2}=e_{3}=0 \quad \rightarrow \sigma_{1}^{2}=\sigma_{2}^{2}=\sigma_{3}^{2}=0$

$X_{n \times 1}=A_{n \times m} F_{m \times 1}$

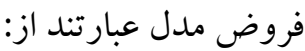

$1-\operatorname{corr}(F s, X j)=\lambda_{j s}$

$2-\operatorname{corr}(F s, F r)=0$

$3-\operatorname{corr}(X i, X j)=\lambda_{j 1} \lambda_{j 1}+\lambda_{j 2} \lambda_{j 2}+\lambda_{j 3} \lambda_{j 3}+\cdots$

فرض دوم متعامد (مستقل) بودن عو امل را نشان مى دهد.

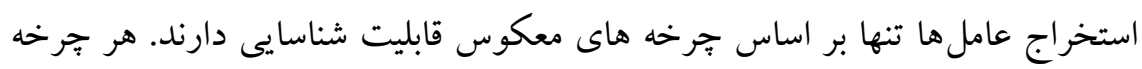

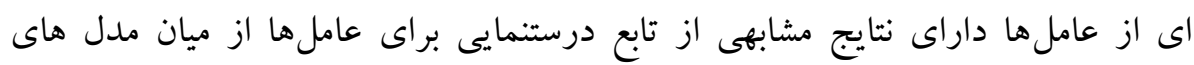

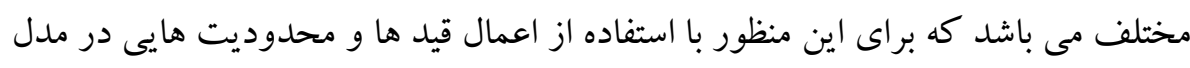
قابليت شناسايى دارند. به منظور اعمال قيدهاى مورد نياز در مدل از روش معرفى شده 
توسط بووين و الياز (ه · (Y) استفاده شده است. بنابر اين فرم تبعى مدل مورد استفاده براى

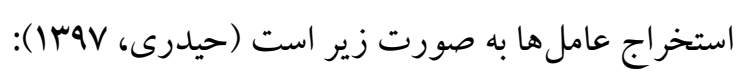

$$
f_{t}^{*}=A f_{t}^{c}-B f_{t}^{y}
$$

كه در آن A و B غيرمنفرد مى باشند. قيدهاى مدل تنها بر بخش قابل مشاهده اعمال

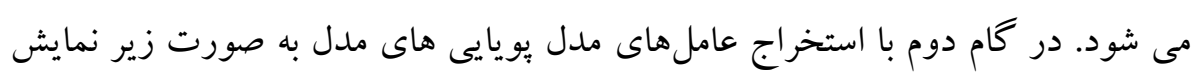
داده مى شود:

$X_{t}^{c}=\lambda^{c} A^{-1} f_{t}^{*}+\left(\lambda^{y}+\lambda^{c} A^{-1} B\right) f_{t}^{y}+e_{t}$

كه در آن

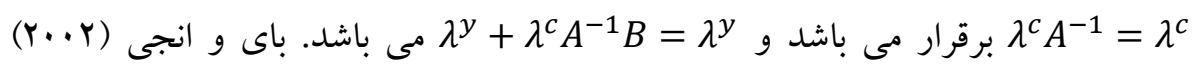

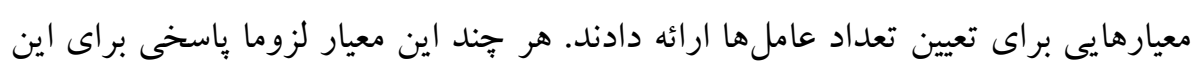

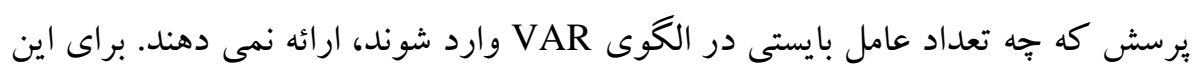
منظور ما حساسيت نتايج به تعداد عامل هاى مختلف را مورد بررسى قرار خو اهيم داد. $I C(k)=\ln \left(V\left(k, \hat{F}^{k}\right)\right)+k g(N, T)$

$$
n\left(V\left(k, \hat{F}^{k}\right)\right)=\min \frac{1}{N T} \sum_{i=1}^{N} \sum_{t=1}^{T}\left(X_{i t}-\lambda_{i}^{k} F_{t}^{k}\right)^{2}
$$

بطوريكه در معادلات فوق T و و ب به ترتيب تعداد متغيرها، تعداد مشاهدات و تعداد عامل ها است.

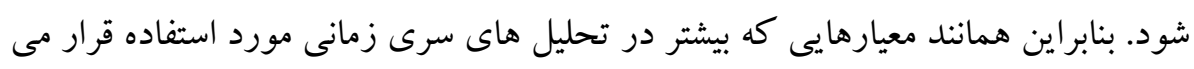

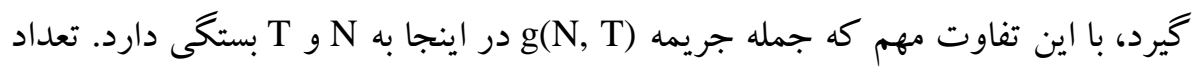

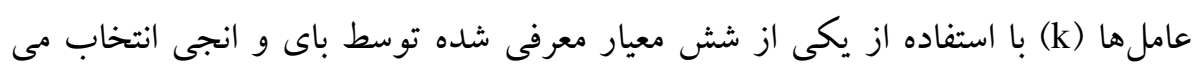

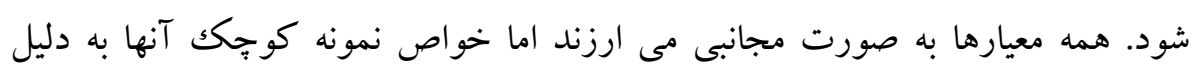

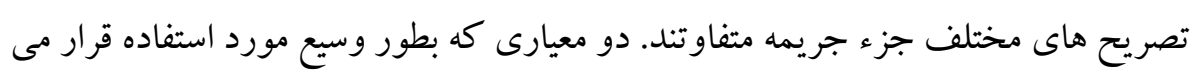

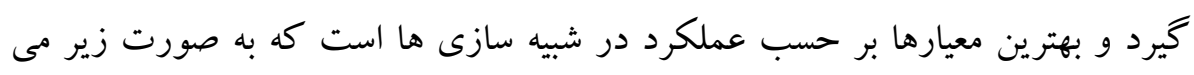




$$
\begin{gathered}
I C_{p 1}(k)=\ln \left(V\left(k, \hat{F}^{k}\right)\right)+k\left(\frac{N+T}{N T}\right) \ln \left(\frac{N T}{N+T}\right) \\
I C_{p 2}(k)=\ln \left(V\left(k, \hat{F}^{k}\right)\right)+k\left(\frac{N+T}{N T}\right) \ln \left(C_{N T}^{2}\right)
\end{gathered}
$$

دو جز براى تشكيل يكك الكوى خودر گرسيون بردارى عامل افزوده (FAVAR) لازم است؛ جز اول الكوى عامل بوياست و جز دوم الكوى خودر گرسيون بردارى با متغيرهاى برى بردي

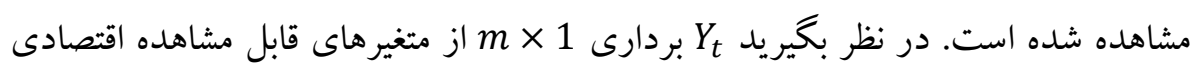

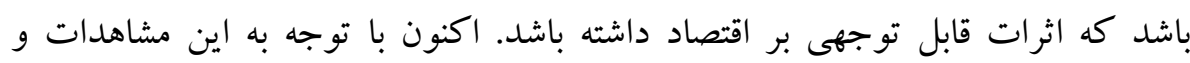

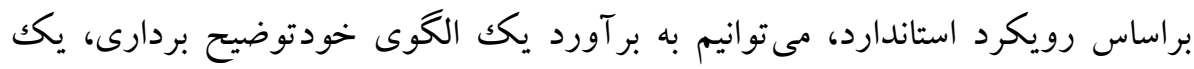

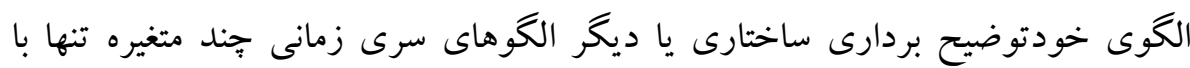

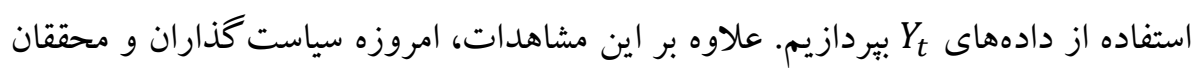

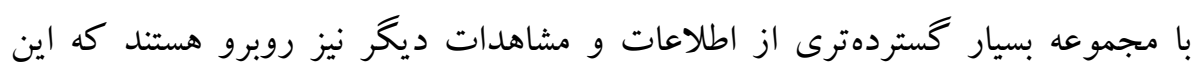

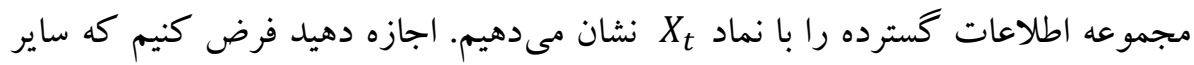

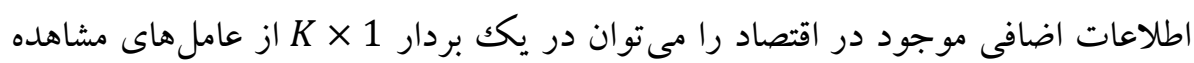

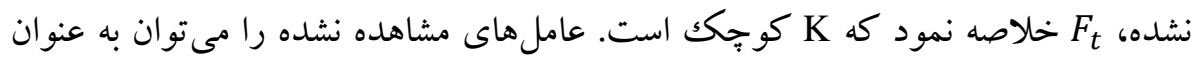
مفاهيم يراكنده همانند فعاليتهاى اقتصادى يا شرايط اعتبارى تصور كرد كه به راحتى در

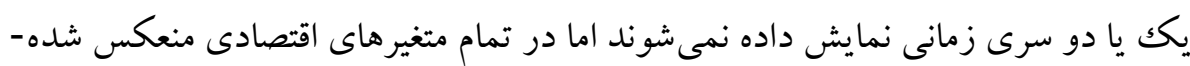

$$
\text { اند. بويايى هاى مركب })
$$

$$
\left[\begin{array}{c}
\mathrm{F}_{\mathrm{t}} \\
\mathrm{Y}_{\mathrm{t}}
\end{array}\right]=\Phi(\mathrm{L})\left[\begin{array}{l}
\mathrm{F}_{\mathrm{T}-1} \\
\mathrm{Y}_{\mathrm{T}-1}
\end{array}\right]+\mathrm{V}
$$

كه در آن (L) جندجملهاى با وقفه از مرتبه محدود d است كه مى تواند شامل محدوديتهاى اوليه هماند ادبيات الكوهاى خودتوضيح بردارى ساختارى باشد. جمله

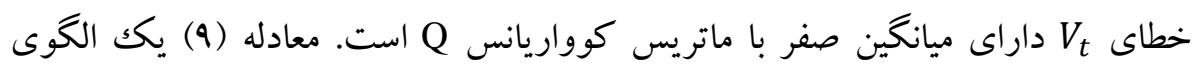
خودرگرسيون بردارى است. اين سيستم به يك الكوى استاندارد خودتوضيح بردارى در خلاصه مى شود. اخر عبارات $Y_{t}$

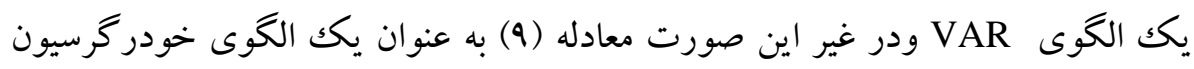
بردارى عامل افزوده (FAVAR) مطرح مى شود. بنابراين نكاشت مستقيمى به نتايج 
خودر گرسيون بردارى وجود دارد و معادله (9) روشى براى ارزيابى نقش نهايى اطلاعات

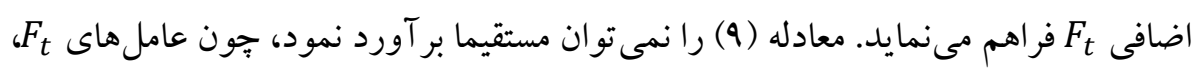

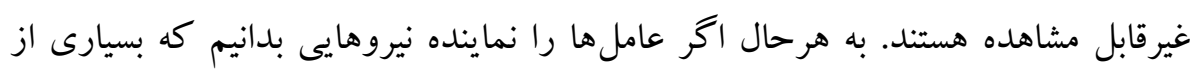

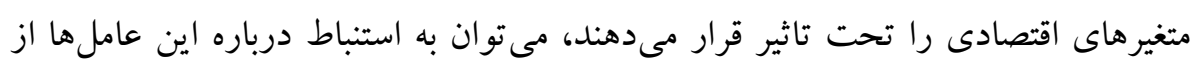
مشاهدات موجود در مجموعه سرىهاى زمانى اقتصادى اميدوار بود. فرض نماييد اطلاعات

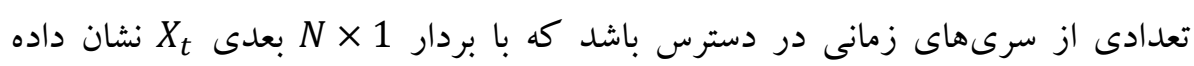

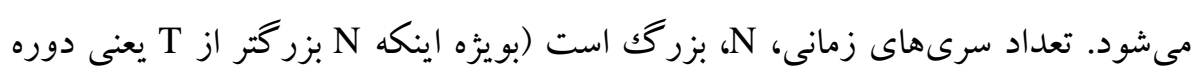
زمانى باشد) بطورى كه عامل هاى غيرقابل مشاهده F و و عامل هاى قابل مشاهد ب

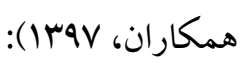

$$
X_{t}^{\prime}=\Lambda^{F} F_{t}^{\prime}+\Lambda^{y} Y_{t}^{\prime}+e_{t}^{\prime}
$$

كه در آن، بردارى N×1 از جملات اخلال با ميانگين صفر كه فرض شده، بسته به اينكه آيا بر آورد با اجزا اصلى باشد يا روش درستنمايى باشد، يا بهطور ضعيف همبسته هستند و يا نيستند.

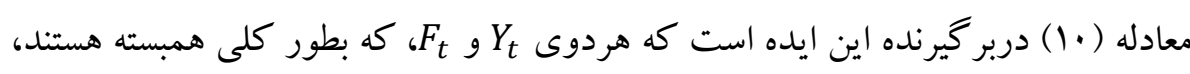
نماينده نيروهايى هستند كه يويايىهاى مشترك كل

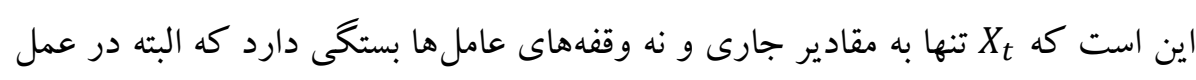

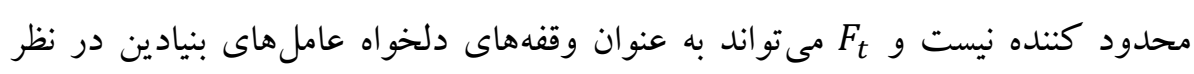

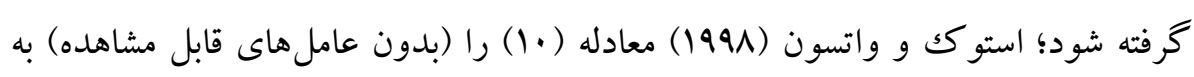
عنو ان يكك الكوى عامل بويا معرفى نمودند.

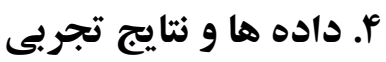

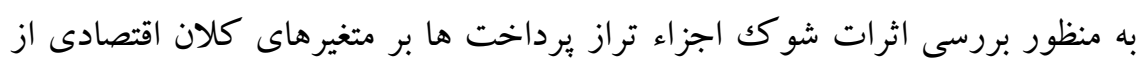

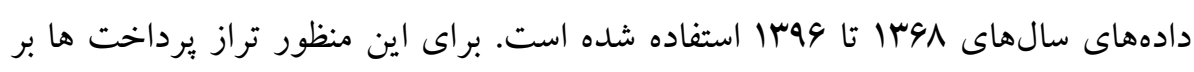

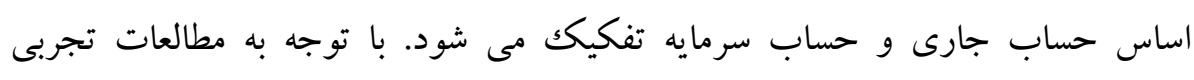




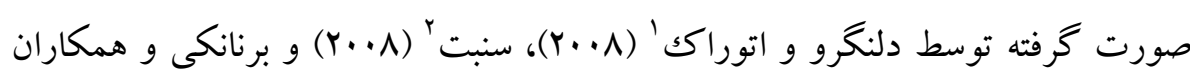

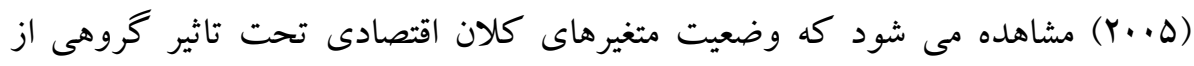
متغيرها به عنوان متغيرهاى بنهان هستند. در اين صورت مجموعه متغيرهاى سازنده عوامل

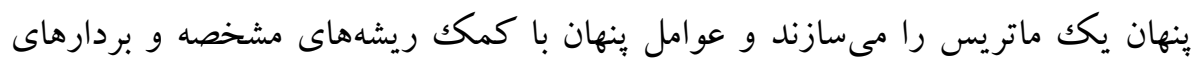

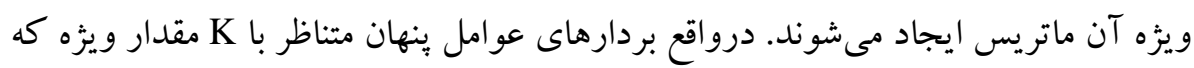
بزر كتر از ساير مقادير ويزه اين ماتريس هستند استخر اج مى شوند. در اين مطالعه متغيرهاى

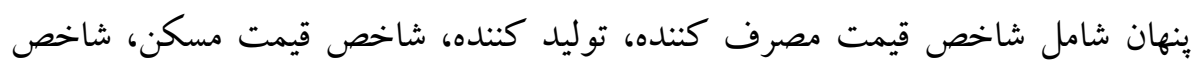
قيمت بخش صادراتى و يا نرخ ارز موثر، نرخ ارز بازارى، صادرات و واردات كالاها و

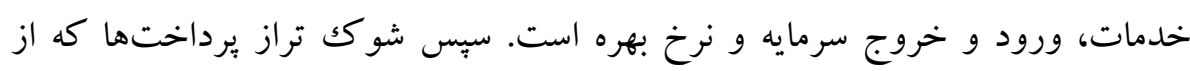

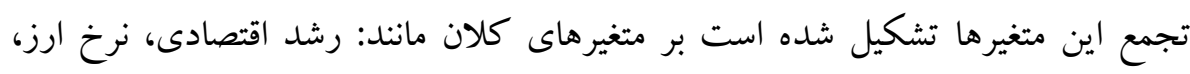

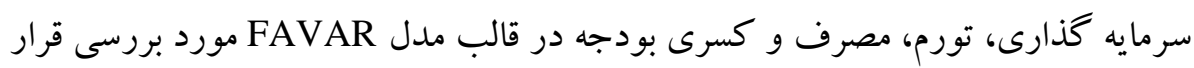

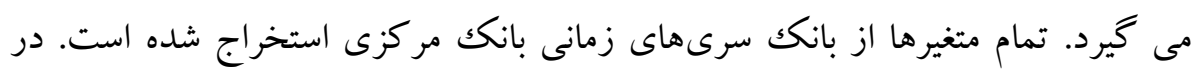

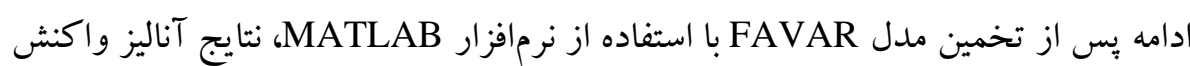

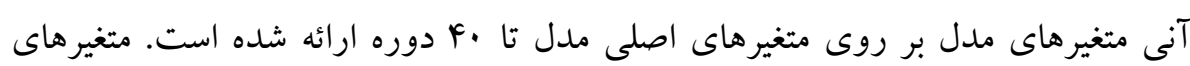

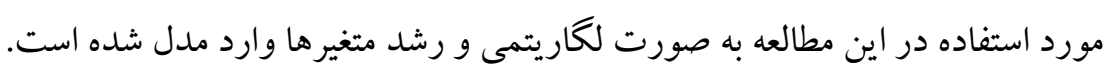

\section{ץ-1 ـ آزمون ريشه واحد متغيرهاى تحقيق}

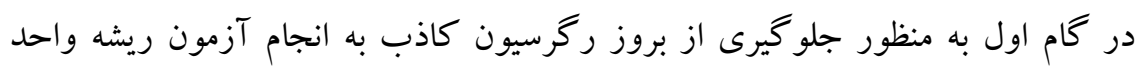

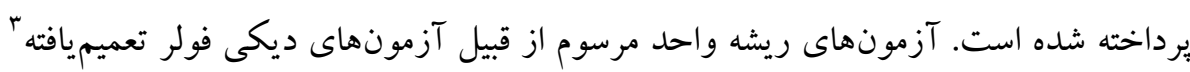

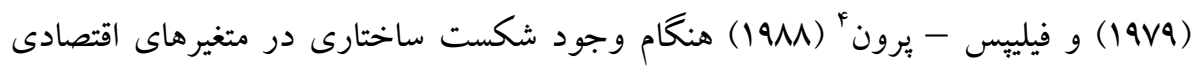
نتايج گمراه كننده گز ارش مى دهند (تورش به سمت عدم رد فرضيه صفر هنگامى كه دادههاى

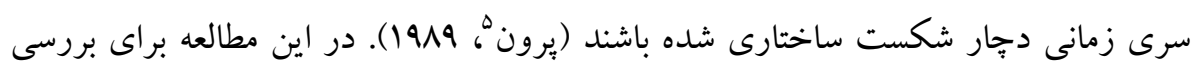

1. Del Negro and Otrok

2. Senbet

3. Augmented Dickey-Fuller

4. Phillips-Perron

5. Perron 
مانايى متغيرها از آزمون ريشه واحد با لحاظ شكست ساختارى استفاده مى شود. به منظور بررسى ريشه واحد با لحاظ شكست ساختارى از آزمون زيوت - اندروز ' استفاده شده است. در اين آزمون فرضيه صفر مبنى بر وجود ريشه واحد است، به طورى كه هيج شكست

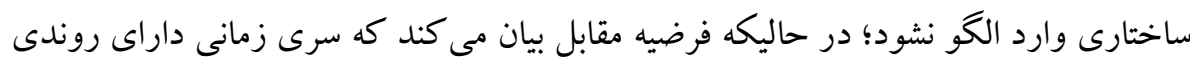

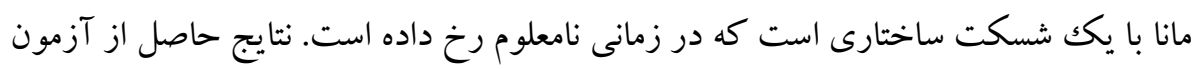

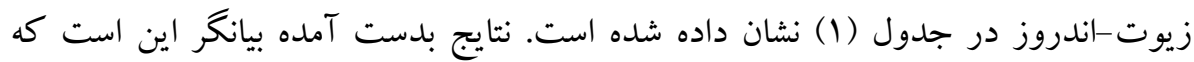
تمامى متغيرهاى تحقيق در حالت روند و عرض از مبداء در سطح خطاى ها درصدى مانا

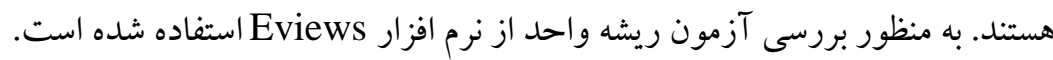

\begin{tabular}{|c|c|c|c|c|c|}
\hline \multicolumn{6}{|c|}{ جدول ا. نتايج حاصل از آزمون ريشه واحد زيوت-اندروز } \\
\hline 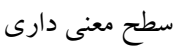 & مقدار بحر انى هـ/ & | آماره آزمون & وقفه & زمان شكست & متغيرها \\
\hline$\% r$ & $-r / 9 r$ & $-\Delta / \notin 9$ & 1 & IrV & رشد توليد ناخالص داخلى \\
\hline$\%$ & $-r / 9 r$ & $-9 / N \Delta$ & 1 & IrA. & رشد حجم يول \\
\hline.$/ 1$ & $-r / 9 r$ & $-F / 99$ & 1 & ITAV & رشد در آمدهاى دولت \\
\hline$\%$ & $-r / 9 r$ & $-\Delta / r)$ & . & $1+4$. & رشد نرخ ارز \\
\hline$\%$. rF & $-r / a r$ & $-F / Y \Delta$ & r & ITVD & 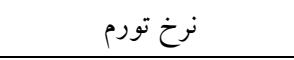 \\
\hline$\cdot \cdots$ & $-r / \notin r$ & $-4 / 91$ & . & $1 \% q$. & نرخ بهره \\
\hline.$\cdot \cdot 1$ & $-r / \notin r$ & $-4 / 91$ & 1 & Irar & رشد حساب جارى \\
\hline$\% \cdots 1$ & $-r / 4 r$ & $-F / \Lambda r$ & 1 & IrA9 & رشد حساب سرمايه \\
\hline.$/ . Y F$ & $-r / 4 r$ & $-\Delta / \Delta 4$ & $\cdot$ & Irat & رشد مخارج مصرفى \\
\hline .1 .19 & $-r / 4 r$ & $-r / \Lambda 9$ & r & ITVF & رشد مخارج سرمايه گذارى \\
\hline
\end{tabular}

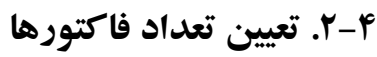
جهت تشخيص مناسب بودن داده ها براى انجام تحليل عاملى، از آزمون KMO استفاده شده است. نتايج در اين مورد در جدول (Y) ارائه شده است.

1. Zivot and Andrews 


\begin{tabular}{|c|c|c|}
\hline $.19 \cdot 9$ & \multicolumn{2}{|c|}{ اندازه كيرى كفايت نمونه كيسرماير } \\
\hline$M N / Y$ & آماره كاى دو & \multirow{2}{*}{ آزمون كرويت بارتلت } \\
\hline$\cdot / \ldots$ & سطح معنى دارى & \\
\hline
\end{tabular}

منع: محاسبات تحقيق

با توجه به اينكه آماره مورد نظر در مورد آزمون KMO بيشتر از ه/ • است، بـ مى توان به اين نتيجه دست يافت كه متغيرها براى تحليل عاملى مناسب هستند. همجِنين با توجه آنه به آماره بدست آمده از آزمون بارتلت، فرضيه صفر آن، مبنى بر اينكه متغيرها مستقل

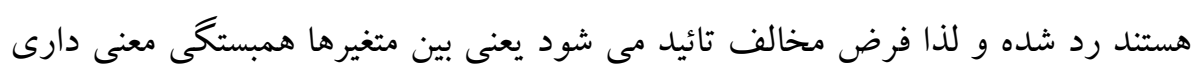
وجود دارد و متغيرها براى تحليل عاملى مناسب هستند.

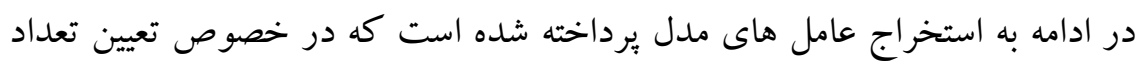

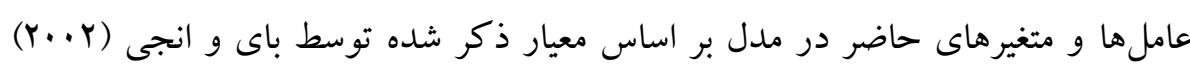

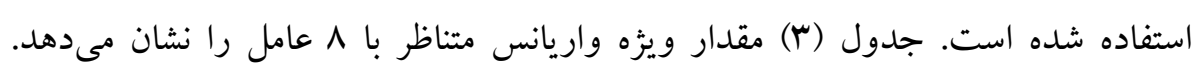

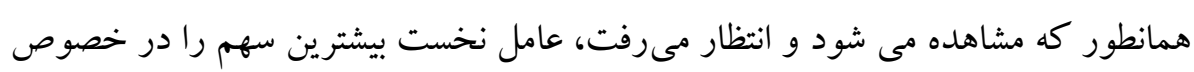

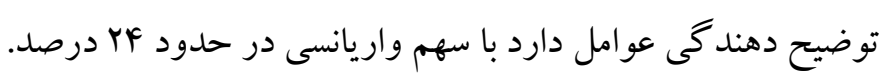

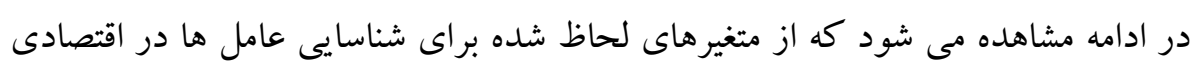

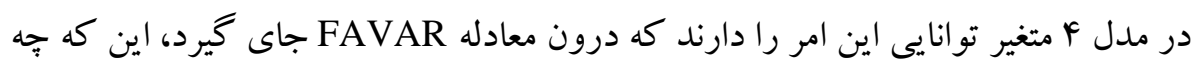

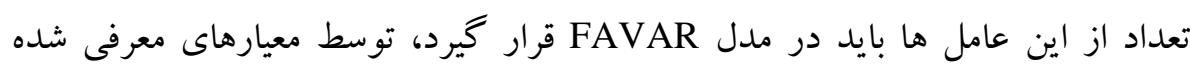

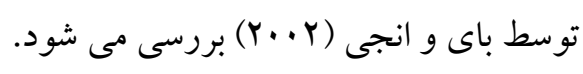




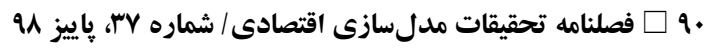

Scree Plot (Ordered Eigenvalues)

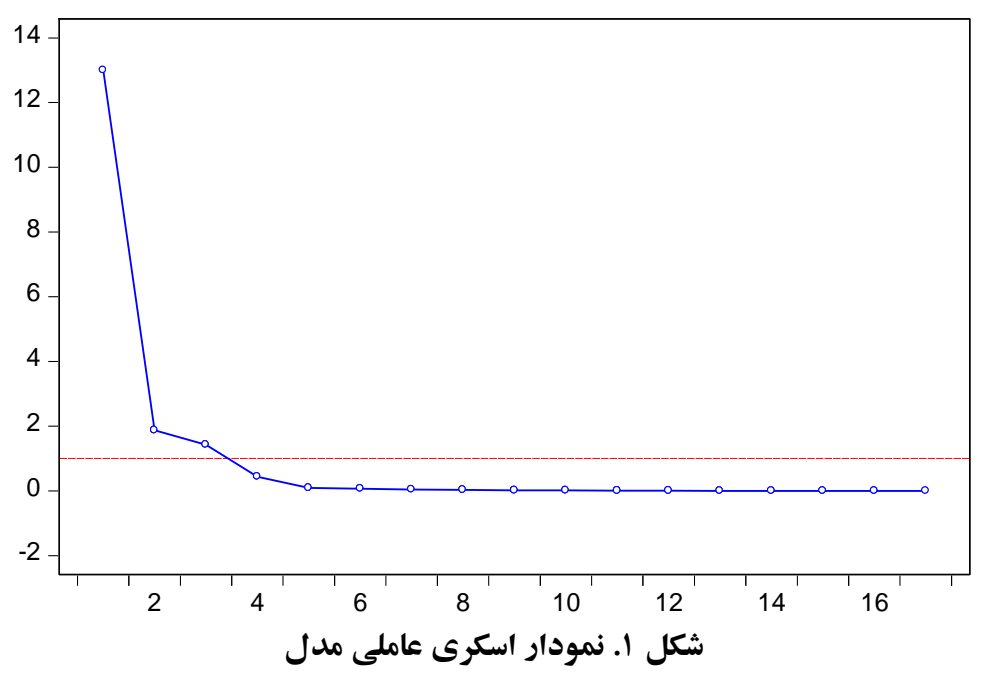

باى و انجى (Y... (Y) معيارهايى را جهت تعيين تعداد عامل ها از متغيرهاى X بيشنهاد

داده اند. در ادامه با استفاده از آماره باى و انجى تعداد عاملهاى مدل بررسى شده است.

\begin{tabular}{|c|c|c|}
\hline \multicolumn{3}{|c|}{ جدول f. آماره باى - انجى } \\
\hline$I C_{p 2}$ & $I C_{p 1}$ & انواع مدل \\
\hline$r$ & F & مدل 1 \\
\hline F & F & مدل r \\
\hline$r$ & F & مدل r \\
\hline$r$ & F & مدل F \\
\hline
\end{tabular}

بر اساس نتايج بست آمده تعداد F عامل جهت بر آورد مدل FAVAR براى تخمين مدل انتخاب شده است. در ادامه لازم است مرتبه بهينه مدل با استفاده از ملاككهاى تعيين وقفه تعيين گردد. در اين تحقيق، وقفه بهينه بر اساس معيار شوارتز انتخاب گرديده است. 
ارزيابى اثرات شوك متغيرهاى تراز برداختها بر متغيرهاى كلان اقتصادى...

جدول ه. تعيين تعداد وقفه هاى بهينه مدل

\begin{tabular}{|c|c|c|}
\hline \multicolumn{2}{|c|}{ آماره هاى اطلاعاتى } & \multirow{2}{*}{ علداد وقفه } \\
\hline آماره شوارتز - بيزين & آماره آكائيك & \\
\hline$-9 / 19$ & $-1 \cdot / r \Delta$ & 1 \\
\hline$*-1 \cdot / 10$ & $-1 \cdot / \mu F$ & r \\
\hline$-1 \cdot / \cdot F$ & $*-1 \cdot 109$ & $r$ \\
\hline$-9 / A F$ & $-1 \cdot / 11$ & r \\
\hline$-9 / 9 V$ & $-9 / \Lambda F$ & $\Delta$ \\
\hline
\end{tabular}

همانطور كه از جدول فوق بيداست، وقفه بهينه در اين مدل بر اساس معيار شوارتز وقفه

دو است. بعد از بررسى تعداد وقفه هاى و فاكتورهاى بهينه در مدل به منظور بر آورد صورت كرفته يا استفاده از آزمون يورتمن بررسى مى شود كه ايا جمالت اخلال داراى خودهمبستكى هستند يا خير.

جدول צ. آزمون يورتمن براى تشخيص خودهمبستكى در جملات اخلال مدل

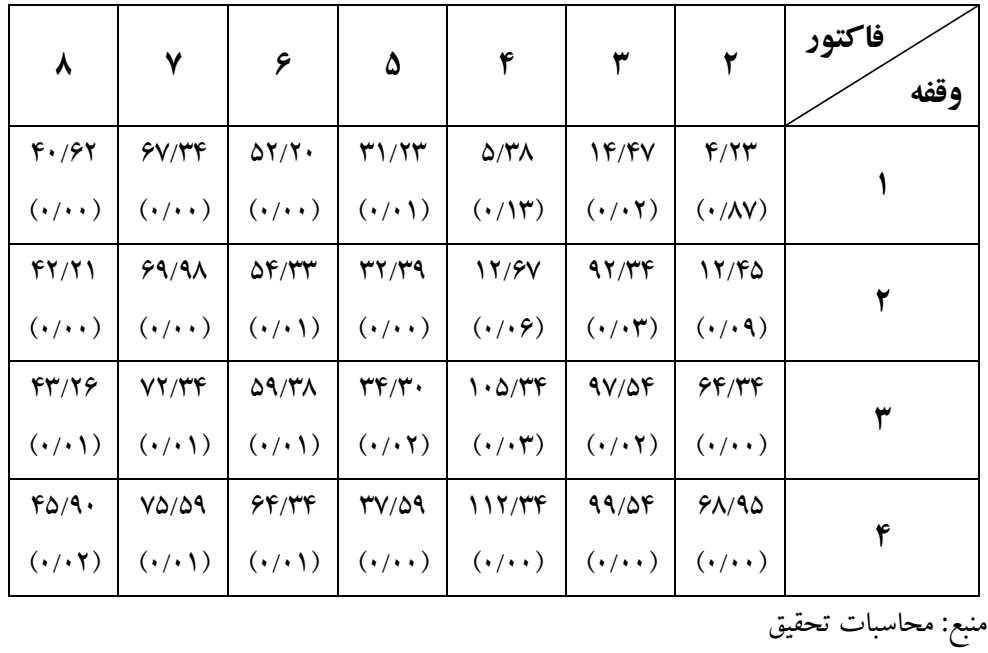

بر اساس نتايج بدست آمده مشخص كرديد كه در وقفه هاى ا و Y و همجنين تعداد فاكتورهاى Y و F در مدل FAVAR بر آورد شده خودهمبستكى در جملات اخلال مدل 
ركرسيونى از بين رفته است. در ادامه به برآورد تاثير شوك تراز يرداخت ها از جانب حساب سرمايه و حساب جارى بر متغيرهاى كلان در اقتصاد اير ان برداخته شده است. براى

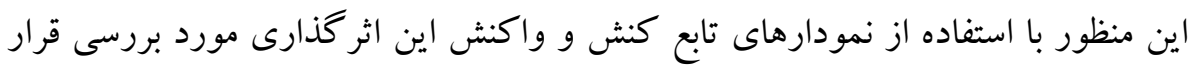
كرفته است.
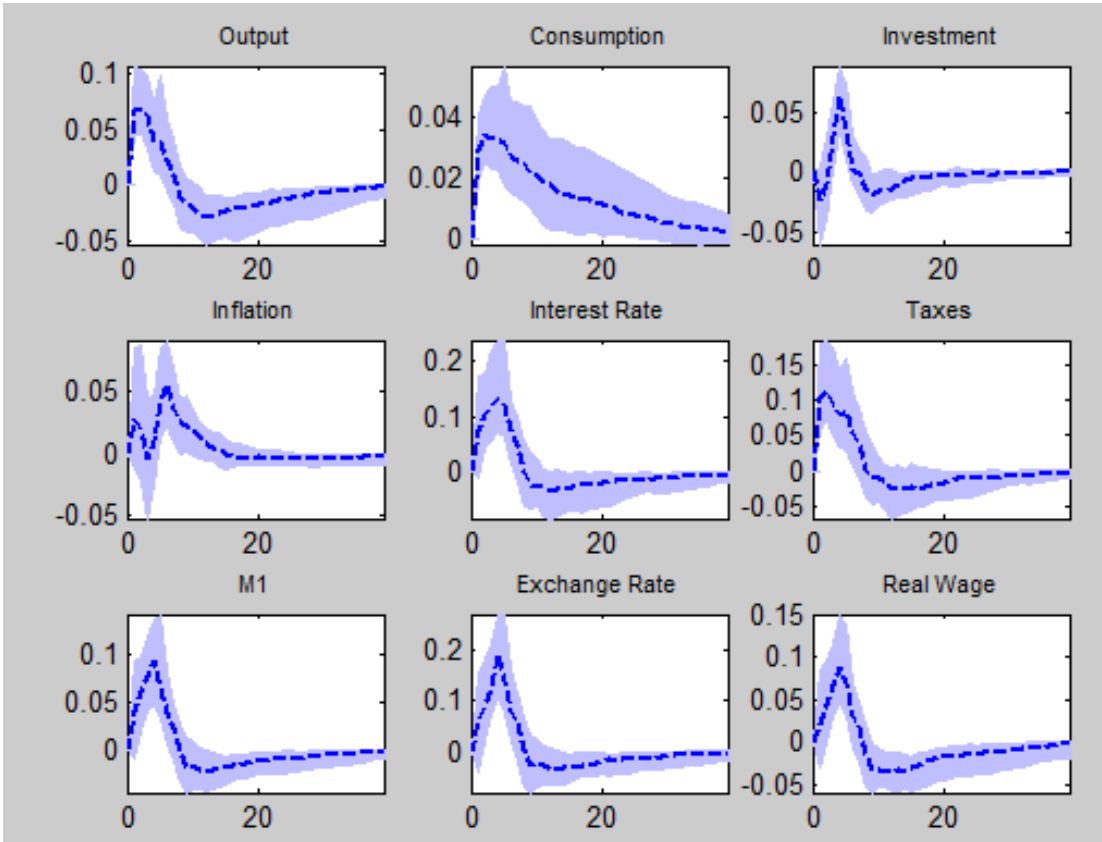

شكل r. نمودارهاى تابع كنش و واكنش مدل FAVAR (شوك حساب جارى)

در نمودارهاى فوق واكنش متغيرهاى كلان اقتصادى به شوك وارد شده از ناحيه حساب جارى مشاهده شده است. به منظور تحليل بهتر نتايج شوكى حساب جارى بر برى متغيرهاى كلان اقتصادى بدن لحاظ نفت در مدل نيز بر آورد شده است كه نتايج در نمودار

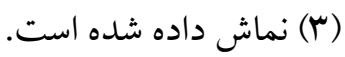




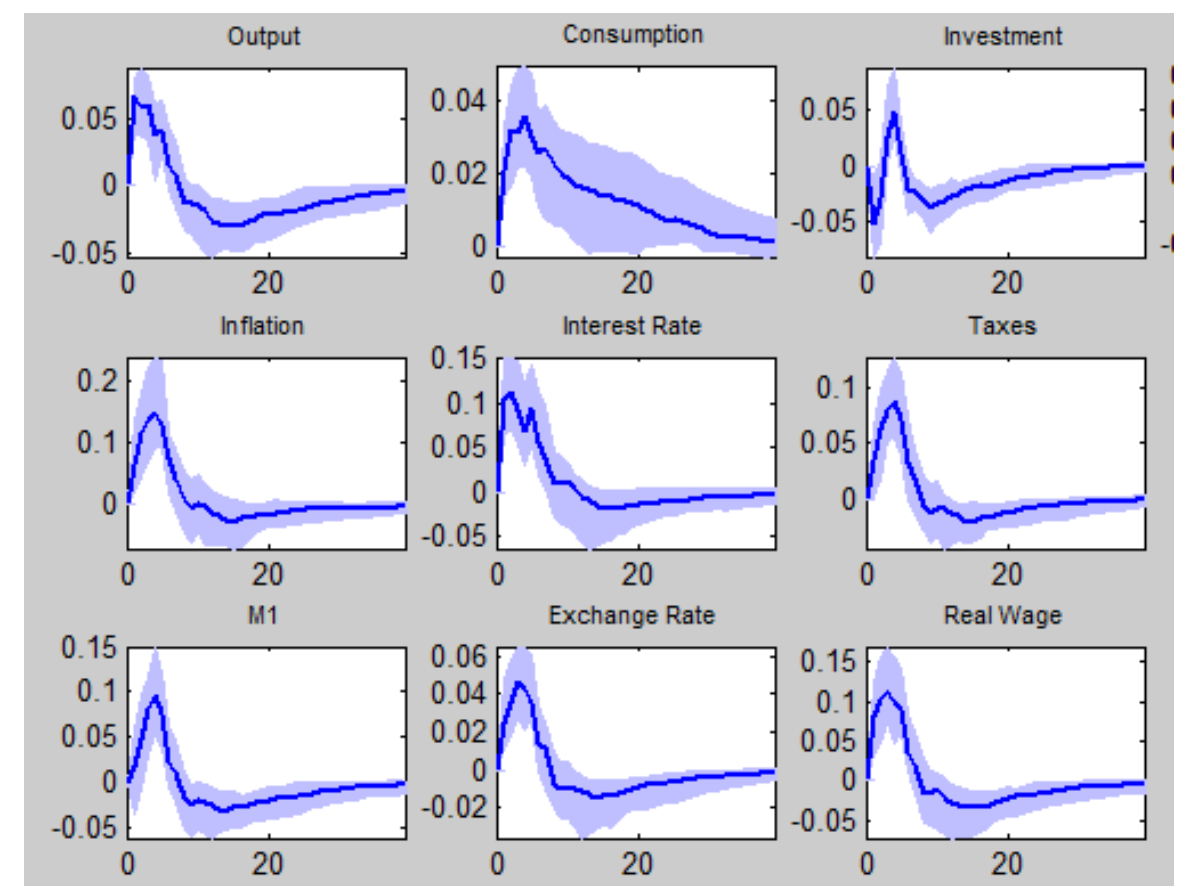

شكل r. نمودارهاى تابع كنش و واكنش مدل FAVAR (شوكى حساب جارى بدون نفت)

با مقايسه نمودارهاى (Y) و (Y) به منظور تحليل تاثير شوك حساب جارى بر متغيرهاى كلان اقتصادى در دو حالت وجود در آمدهاى نفت و عدم وجود در آمدهاى نفتى مشاهده مى شود كه واكنش مخارج مصرفى بخش خصوصى به يك و احد تكانه وارد شده از ناحيه شوكى حساب جارى به گونهاى است كه در ابتدا اين تاثير مثبت و افزايشى بوده است اما

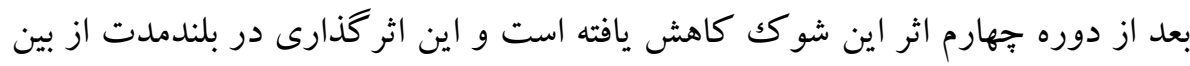

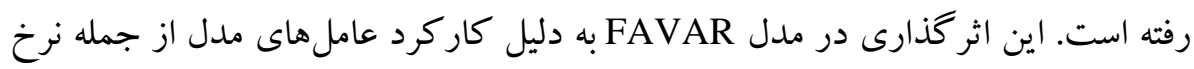
بهره و نرخ ارز با ميزان سريع ترى رخ داده است. با توجه به اينكه افزايش در حساب جارى

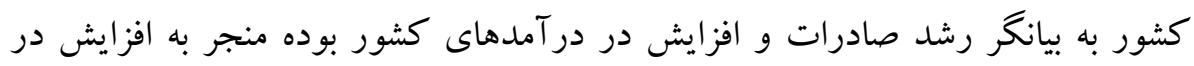
قدرت خريد خانوارها شده و اين شوكى درآمدى منجر به افزايش در مخارج مصرفى آنها شده و اثر اين شوك در بلندمدت به دليل تعديل در الكوى مصرفى آنها از بين رفته است. بر اساس نمودار واكنش سرمايه كذارى بخش خصوصى به يكك واحد تكانه وارد شده از 
ناحيه حساب جارى به گونه اى است كه در ابتدا اين تاثير منفى و كاهشى بوده است و اين

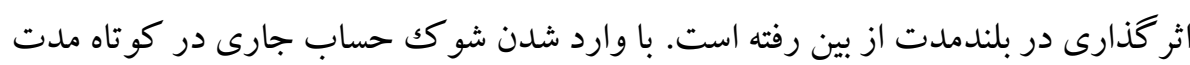

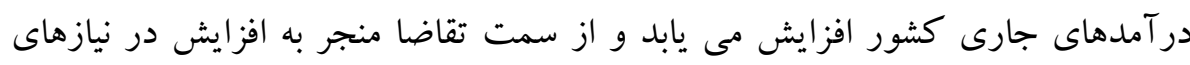
مصرفى خو اهد شد اما با تعديل در انتظارات خانوارها منجر به كاهش در در تمايل بس بس انداز و و سرمايه گذارى شده و در بلندمدت اين الكوى مصرفى تعديل شده و اثر آن از بين رفته

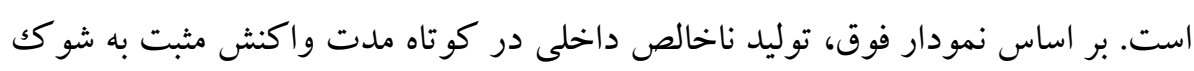

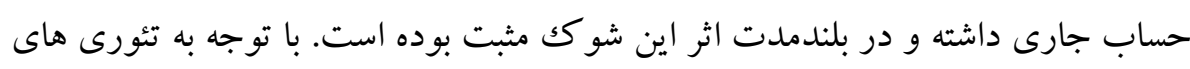

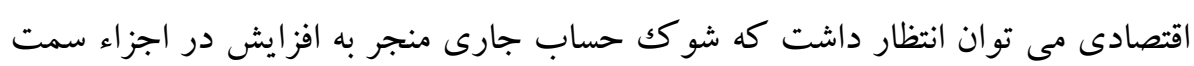

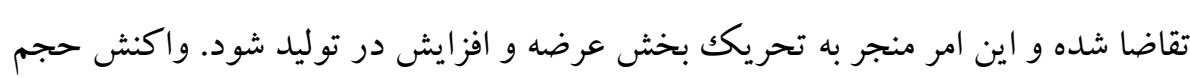

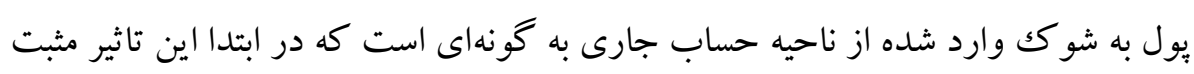

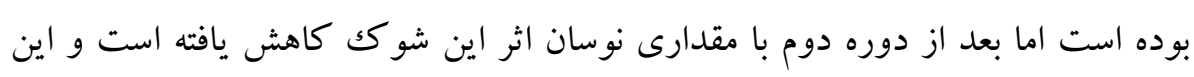

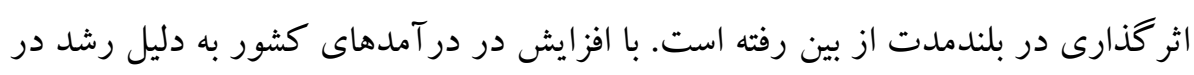

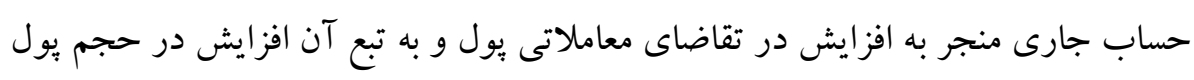

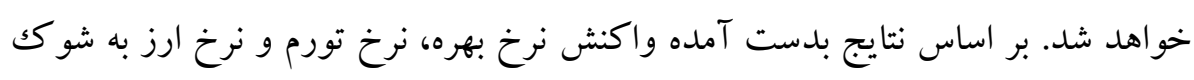

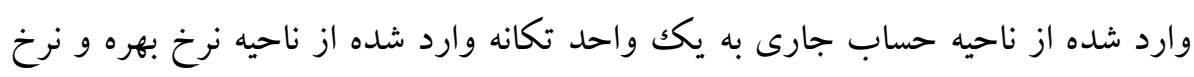
تورم به گونهاى است كه در كوتاه مدت تاثير اين شوكك ها مثبت بوده است اما در ميان

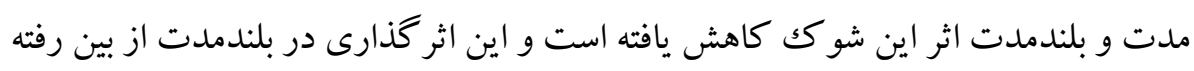

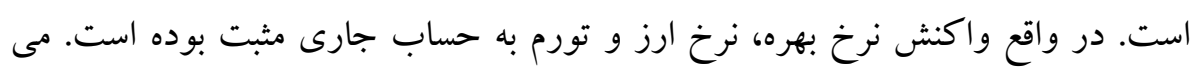
توان انتظار داشت كه با افزايش در حساب جارى و افزايش در سطح تقاضاى كل اقتصاد

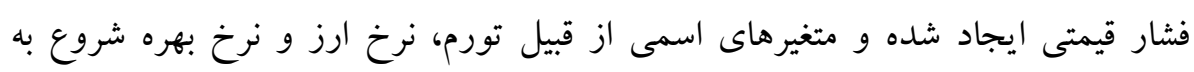

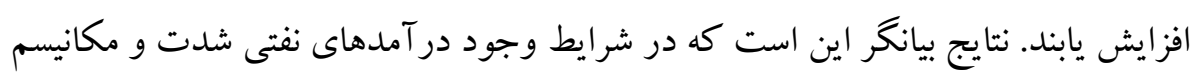
اثر گذارى شو كك حساب جارى بر متغيرهاى كلان اقتصادى شديدتر بوده است. به عنوان مثال مشاهده مى شود كه واكنش مثبت نرخ ارز به شوكى حساب جارى در شرئ شريط 
ارزيابى اثرات شوكى متغيرهاى تراز برداختها بر متغيرهاى كلان اقتصادى...

در آمدهاى نفتى بيشتر بوده است كه انتظار مى رود با جريان در آمدهاى نفتى و تزريق ارز به بازار روند اثر كذارى اين متغير بر ساير متغيرهاى كلان اقتصادى بهبود بيدا كند. در ادامه به بررسى تاثير شوكى حساب سرمايه بر متغيرهاى توضيحى مدل برداخته شده است كه نتايج آن در نمودارهاى زير نمايش داده شده است.
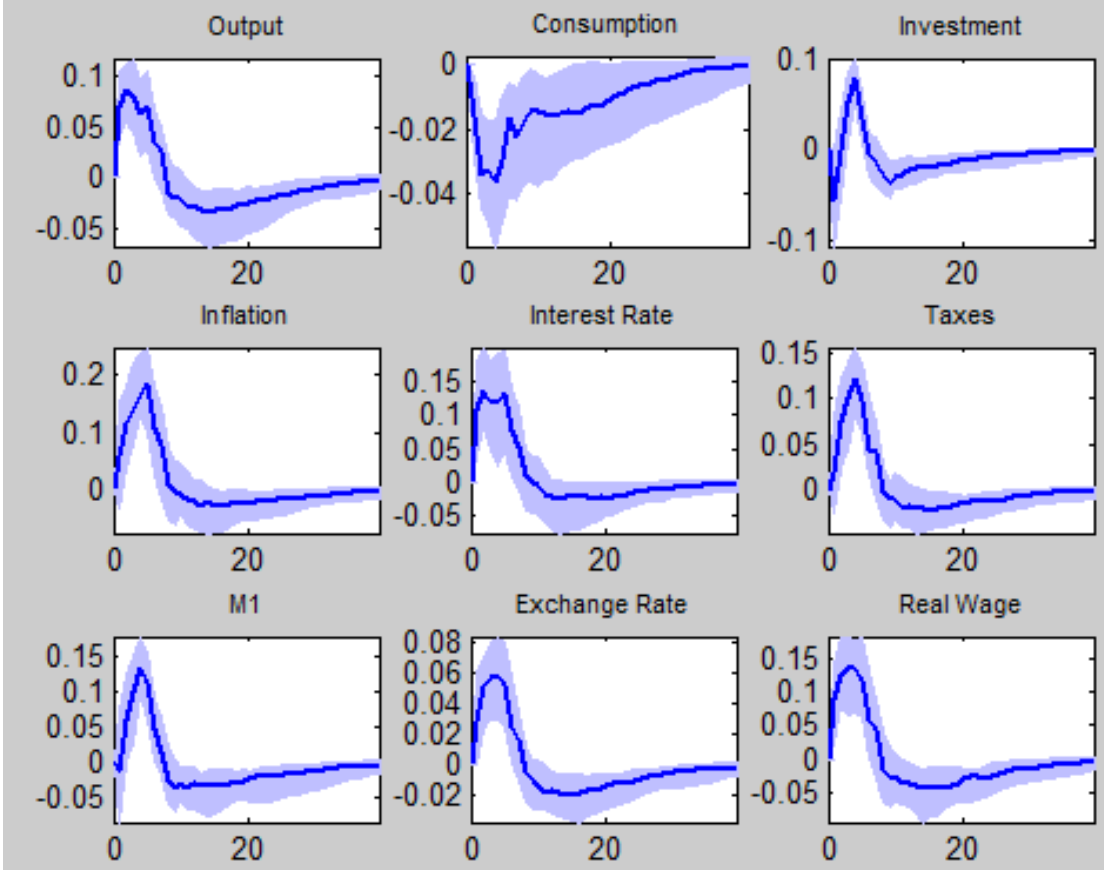

شكل †. نمودارهاى قابع كنش و واكنش مدل FAVAR (شوك حساب سرمايه)

در نمودارهاى فوق واكنش متغيرهاى كلا ن اقتصادى به شوك وارد شده از ناحيه

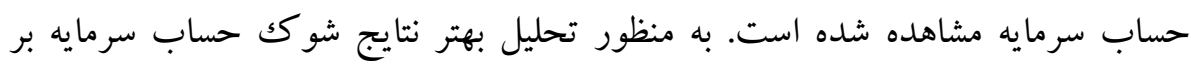
متغيرهاى كلان اقتصادى بدن لحاظ نفت در مدل نيز بر آورد شده است كه نتايج در نمودار

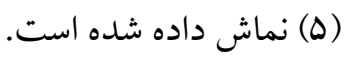




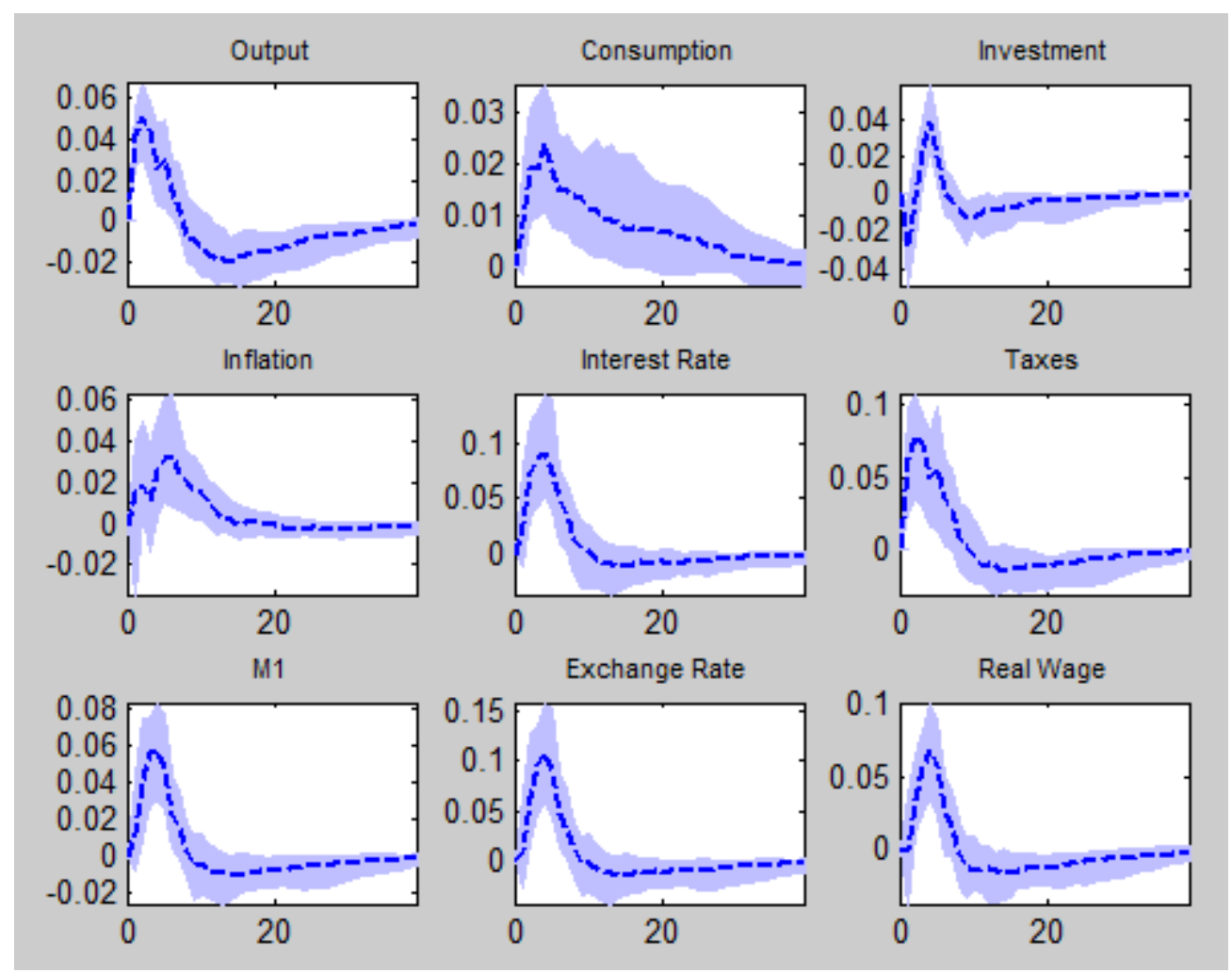

شكل ه. نمودارهاى تابع كنش و واكنش مدل FAVAR (شوك حساب سر مايه بدون نفت)

با مقايسه نمودارهاى (F) و (D) به منظور تحليل تاثير شو كك حساب جارى بر متغيرهاى كلان اقتصادى در دو حالت وجود در آمدهاى نفت و عدم وجود در آمدهاى نفتى مشاهده مى شود كه واكنش مخارج مصرفى بخش خصوصى به يكك واحد تكانه وارد شده از ناحيه حساب سرمايه به گونهاى مىباشد كه در ابتدا اين تاثير كاهشى بوده است اما بعد از دوره

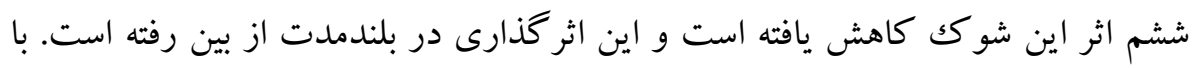
وارد شدن شوك حساب سرمايه مى توان انتظار داشت كه ميزان استقراض دولت از

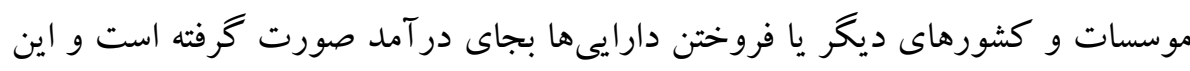

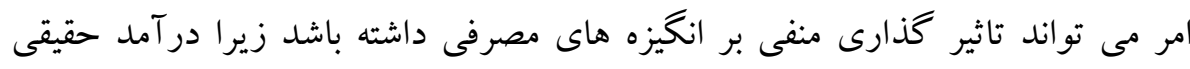

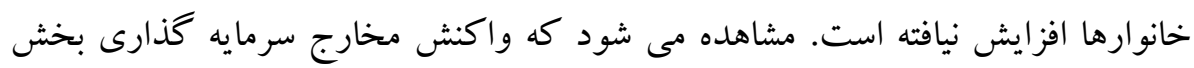


خصوصى به گونهاى است كه با وارد شدن يكك واحد تكانه از سمت حساب سرمايه در كوتاه مدت سرمايه گذارى بخش خصوصى افزايش مى يابد اما بعد از دوره جهارم اثر

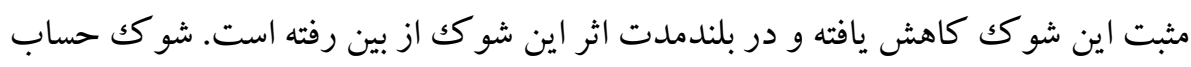

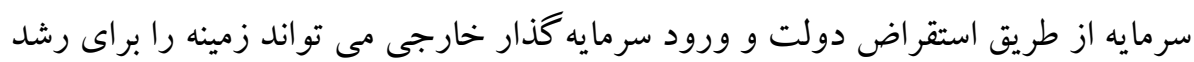

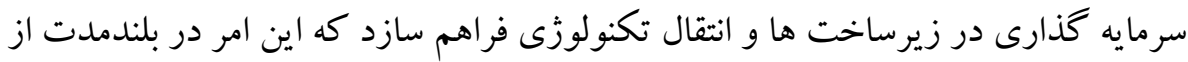

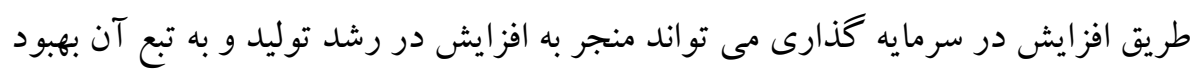

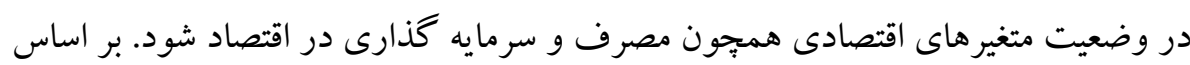
نتايج بدست آمده واكنش نرخ بهره، نرخ تورم و نرخ ارز به شوك وارد شده از ناحيه

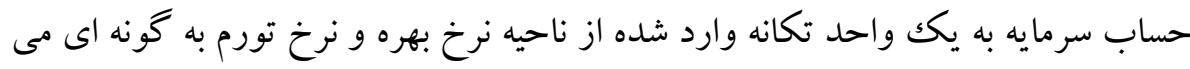

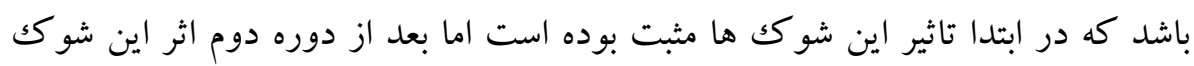
كاهش يافته است و اين اثركذارى در بلندمدت از بين رفته است. در واقع واكنش نرخ بهره، نرخ ارز و تورم به حساب سرمايه مثبت بوده است. همجنين نتايج نشان دهنده اين

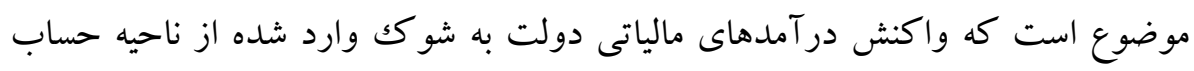
سرمايه به گونهاى است كه در كوتاه مدت اثر اين تكانه مثبت است و در بلندمدت اثر اين شوك از بين رفته است. با بررسى توابع كنش و واكنش براى تعداد عامل هاى لحاظ شده

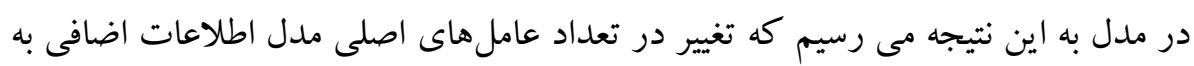

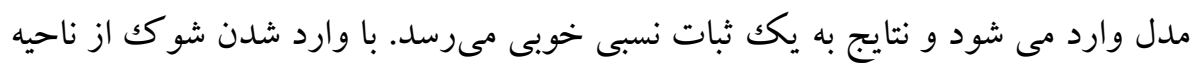
حساب سرمايه و نقل و انتقال در سرمايه و دارايىها منجر به افزايش در تقاضاى ارز و فشار تقاضاى خواهد شد كه به دنبال آن نرخ تورم يا سطح عمومى قيمت ها در داخل كشور

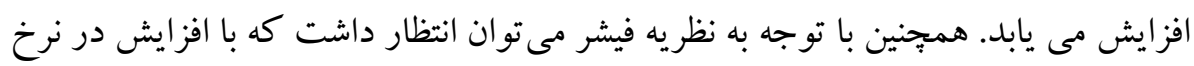
تورم نرخ بهره نيز افزايش خواهد يافت. 


\section{ه. نتيجه كيرى}

در اين تحقيق با استفاده از مدلها خودرگرسيون بردارى عامل افزوده (FAVAR)، اقدام به بررسى توابع واكنش آنى متغيرهاى كلان اقتصادى به شوك وارد وارد شده از اجزاء

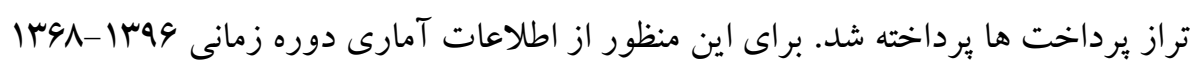

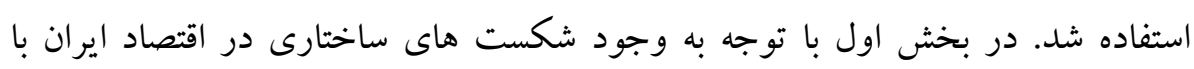
استفاده از آزمون زيوت - اندروز به بررسى مانايى متغيرها برداخته شد. سبّ به به استخراج

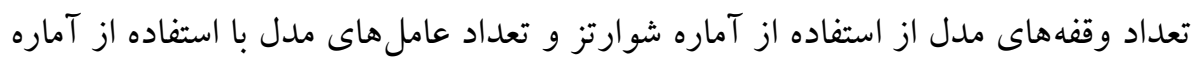

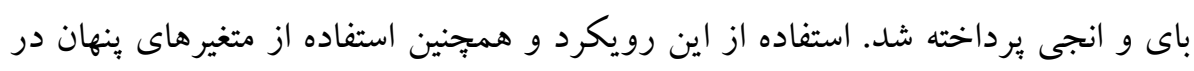
ساختار مدل با الهام از مطالعات تجربى منجر به كسب نتايج واقعى تر و واكنش سريع

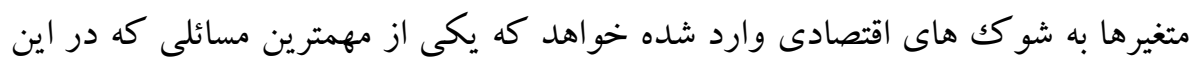

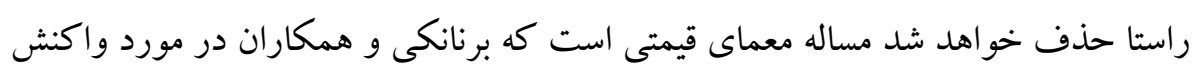
متغير نرخ تورم به شوكك هاى سياستى مطرح كردند. نتايج بدست آمده بيانكر اين بود كه

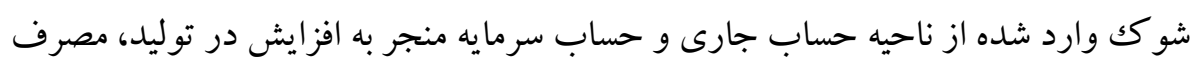

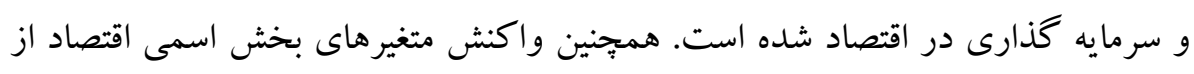
قبيل نرخ تورم و نرخ بهره به شوك وارد شده مثبت بوده است. مقايسه نتايج بدست آمده وندي

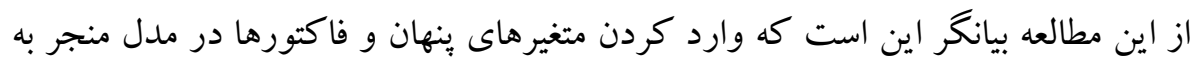
واكنش سريع تر متغيرهاى كلان اقتصادى به شوك وارد شده از ناحيه اجزاء تراز يرداخت

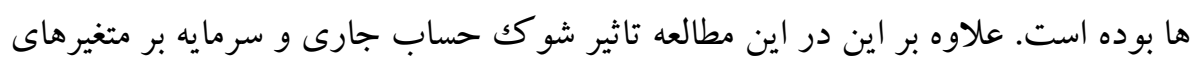
كلان اقتصادى در دو حالت وجود و عدم وجود در آمدهاى نفتى مورد ارزيابى قرار گرفت

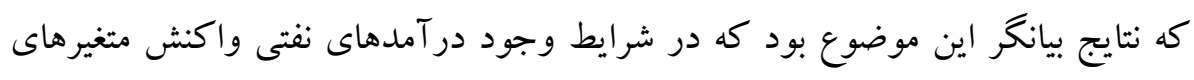
كلان اقتصادى به شوكك وارد شده سريع تر و بيشتر بوده است. مقايسه نتايج بدست آمده از اين مطالعه بيانگر اين است كه نتايج با مطالعات هيناينى ايتا و همكاران (Y) (Y) كه نشان دادند كه حساب جارى تاثير مثبت بر سرمايه گذارى و تاثير منفى بر نرخ ارز داشته مخالف بوده اما با تاثير مثبت حساب جارى بر نرخ تورم، نرخ بهره و 
توليد ناخالص داخلى مطابقت داشته است. هميجنين نتايج اين مطالعه با مطالعه داس (19 (Y) كه نشان داد رابطه مثبت و معنى دارى بين حساب جارى و توليد ناخالص داخلى وجود

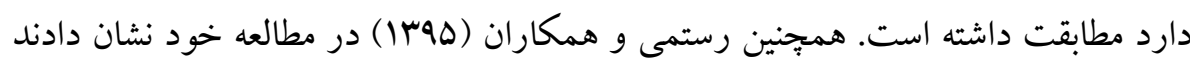

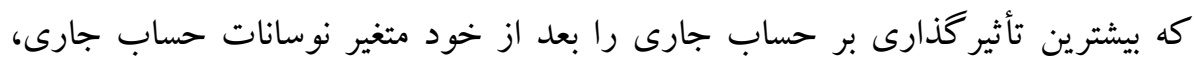
متغيرهاى قيمت سهام و نسبت نوسانات حساب جارى به توليد ناخالص داخلى، و نرخ بهره اسمى دارند. علاوه بر اين كمترين توضيح دهندگى در نوسانات حساب جارى مربوط به متغيرهاى توليد ناخالص داخلى و قيمت مصرف كننده است كه در برخى موارد از قبيل توليد و تورم با اين مطالعه مطابقت داشته و در ساير موارد در تضاد بوده است. لازم به ذكر

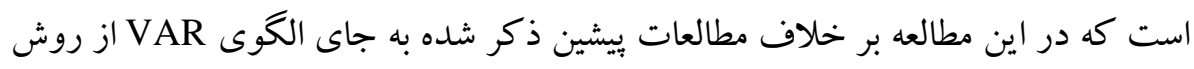

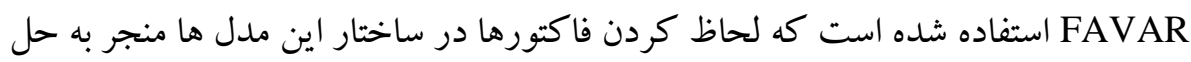
مشكل معماى قيمتى و واكنش سريع تر متغيرها به شو كك هاى وارد شده خو اهد بود.

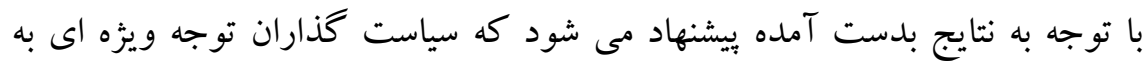

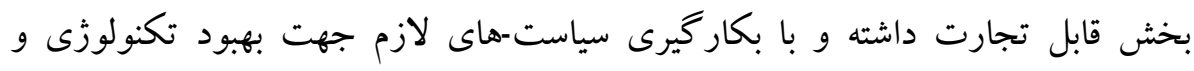
روشهاى نوين توليد و افزايش بهرهورى بخش توليد، به بهبود صادرات و افزايش قدرت

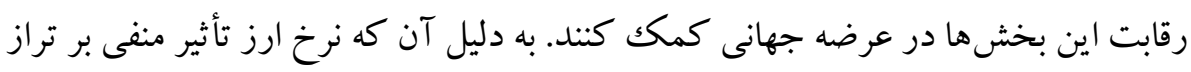

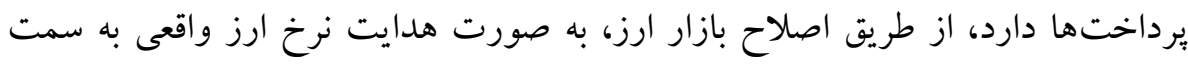

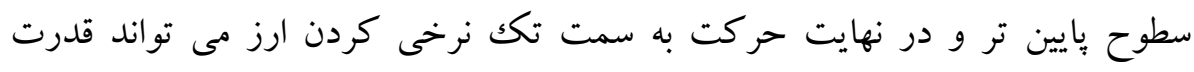

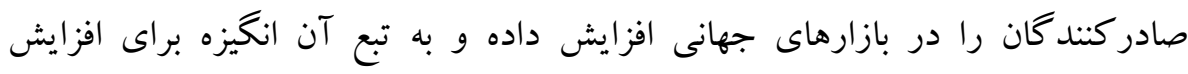

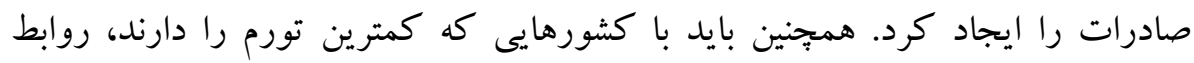
تجارى برقرار كرد. همجنين ضرورت دارد سياست هاى تجارى بيشتر حول محور اتحاديه هاى اقتصادى شكل بحيرد كه ايران در آنها عضويت دارد. تغيير و كاهش تعرفه هاى بايد مد نظر قرار كيرد. اين كار را از دو جهت مى توان بررسى كرد: اولا قيمت محصولات

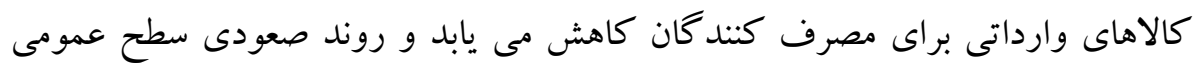

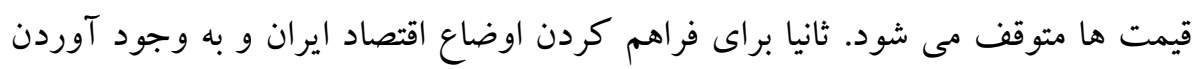


فضاى رقابتى براى بيوستن به سازمان تجارت جهانى آمادگى لازم ايجاد مى شود. همبِنين

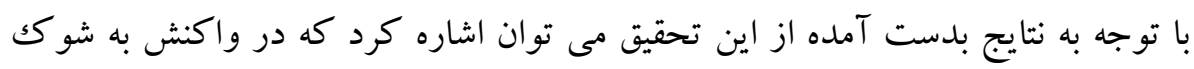

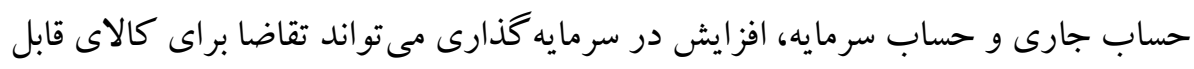
تجارت را افزايش دهد، كه اين امر به دليل ماهيت واردات كالا در ايران (واسطهاى،

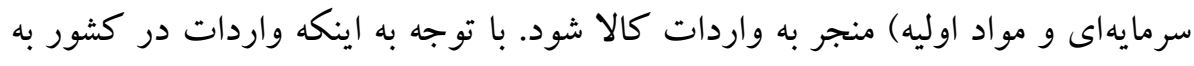

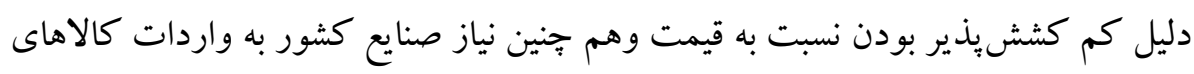

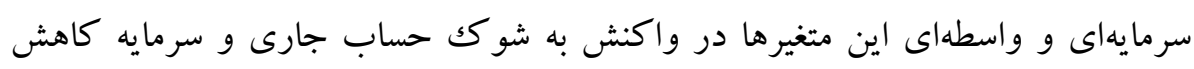

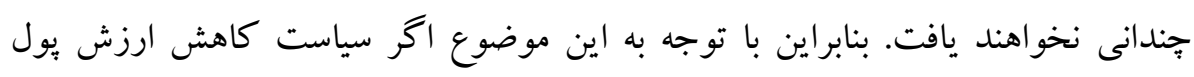
همراه با كاهش مخارج دولتى وآزاد سازى تجارى باشد، اثرات با اهميت ترى بر بر تراز

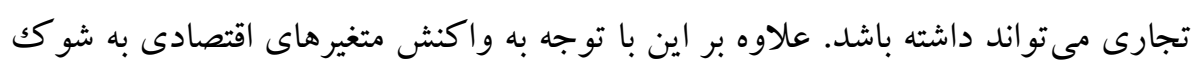

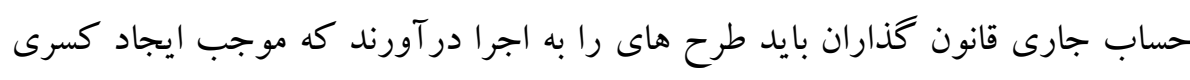
حساب جارى نغردد، و هم جنين اخذ سياستهاى بـولى مناسـب براى كاهش كسرى حساب جارى ضرورى به نظر مىرسد. 
- Acaravci A, Ozturk I (2015), An application of Thirlwall's law to the South African economy: Evidence from ARDL bounds testing, African Journal of Business Management, 3. 717-711 (in Persian).

- Ahmadi Shadmohari, Mohammad Taher and Ahmadian Yazdi, Farzaneh (2012), Investigating the Effect of Real Exchange Rate on Iran's Non-Oil Trade Balance in Trade Relations with Germany; Journal of Regional Economics and Development, 19, 4, 155-114 (in Persian).

- Azimi Seyed Amir, Nofaresti Mohammad (2015), Investigating the Relationship between Government Budget Deficit and Trade Balance in Iran Within a Dynamic Macroeconomic Model. Sustainable Development Research (Economic Research). 7 (8) (in Persian).

- Azizi Vahid, Mehregan Nader, Yavari Gholamreza (2014). Testing the Balance of Payments Growth Model in Iranian Agricultural Sector, Quarterly Journal of Fiscal and Economic Policy, 2 (1): 1-30 \{in persian\}.

- Babazadeh, Mohammad; Farrokhnejad, Farshid \& Aghababaei, Mohammad Ibrahim (2012), Short-term and Long-Term Impacts of Currency Exchange Rate on Banks Currency Profitability in Vector Error Correction Model, Quarterly Journal of Money and Economics, 9, 225205 (in Persian).

- Bismarck. C (2017), Balance of Payments Constrained Growth Model: Evidence for Bolivia 9421-7007, MPRA Working Paper, No. 2132, University Library of Munich, Germany.

- Das, D.K. (2016): Determinants of Current Account Balance in the Global Economy: A Dynamic Panel Analysis. Journal of Economic Structures, 5(8), pp. 2-24.

- Database of Economic Times Series; Central Bank of the Islamic Republic of Iran.

- Delavari Majid, Esfandiari Ali Asghar, Aghazadeh Kamali Nasr al-Din (2013), Analysis of Balance of Payments Impact of Foreign Exchange Market Changes: A Case Study of Iran. Journal of Economic Development Research, 4 (2), 23-34 (in Persian).

- Eita, J. H., Manuel, V. and Naimhwaka, E. (2018). Macroeconomic Variables and Current Account Balance in Namibia. MPRA Paper No. 88818.

- Farahani, Mehdi, Marzban, Hossein, Dehghan Shabani, Zahra and Akbarian, Reza. (2017). Theory of Effect of Interest Rate Shock on Macroeconomic Variables in Iran with FAVAR Model Approach. Iranian Journal of Applied Economic Studies, 7 (25), 29-54 (in Persian). 
- Garcimartín, C., Rivas, L., Martínez, P., (2010). On the role of relative prices and capital flows in balance-of-payments constrained growth: the experiences of Portugal and Spain in the Euro Area. Journal of PostKeynesian Economics, 33 (2). 281-306.

- Ghaderi, Jaafar, Samadi, Ali Hossein, Ghaderi Sani, Betol. (2016). Impact of budget deficit shocks on current account deficits in the presence of output shocks: Investigating the phenomenon of "double divergence" in the Iranian economy. Parliament and Strategy, 23 (85), 223-246 (in Persian).

- Ghaffari, Hadi Jalali, Mehdi and Chegini Ashtiani, Ali (2017), Investigation and Forecasting the Effects of Exchange Rate Increases on Economic Growth of Major Sectors of Iranian Economy; Quarterly Journal of Economic Growth and Development Research, 10, 58-41 (in Persian).

- Gorji, Ebrahim and Alipourian, Masoumeh (2006), Analysis of the Effect of Trade Liberalization on Economic Growth of OPEC Member States, Journal of Business Research, 40, 203-187 \{in persian\}.

- Heidari Hassan (2016), Designing a FAVAR for the Iranian Economy with Emphasis on Oil and Monetary Shocks. Journal of Economic Modeling Research, 23 (3), 13-37 (in Persian).

- Kazerouni, Alireza and Mojiri, Hadi (2010), Investigation of the Depreciation of National Currency on Iran's Trade Balance with Six Selected Business Partners (AutoRegressive Distributed lags); Iranian Economic Research Quarterly, 4, 102-77 (in Persian).

- Kueh, S.H.J. (2015), Essays on Current Account Imbalances in European Countries, Theses and Dissertations Paper 887.

- Lotfali Pour Mohammad Reza, Spring Bazargan (2016), Investigating the Effects of Effective Real Exchange Rate Changes, Exports and Imports on Iran's Trade Balance. Sustainable Development Research (Economic Research), 1 (1), 2-1 (in Persian).

- Mahdavi, Abolghasem and Javadi, Shahin (2005), Testing the Relationship of Foreign Trade and Economic Growth in Iran, Journal of Economic Research, 4, 19-1 (in Persian).

- Marzban, Hossein and Dehghan Shabani, Zahra and Akbarian, Reza and Farahani, Mehdi (2016). Monetary Policy Performance Evaluation in Iran, Quarterly Journal of Quantitative Economics, 4 (2), 71-92 (in Persian).

- McCombie, J., Thirlwall, A., (1994). Economic growth and the balanceof-payments constraint. MacMillan Press, Basingstoke; St. Martin's Press, New York. 
ارزيابى اثرات شوكى متغيرهاى تراز يرداختها بر متغيرهاى كلان اقتصادى... $\square$ ب.

- McCombie, JSL (2011), Criticisms and Defences of the Balance of Payments Constrained Growth Model: Some Old, Some New', PSL Quarterly Review, 13. 121-147

- Najjarzade, Reza and Shaghaghishahri, Vahid (2006)., Factors Affecting Iran's Current Account Deficit,Journal of Economic Research (Tahghighat- E- Eghtesadi), 71, 355-399 130 (in Persian).

- Noferesti, M., Norouzi, Z. (2010). Balance of Payments as a Monetary Phenomena: A Study within a Small Scale Structural Macroeconometric Model Framework. Journal of Economics and Modeling, 1(2), 105-130 (in Persian).

- Nouri, M., Navidi, H. (2013). The Exchange Rate Risk and Non-Oil Export in Iran. Quarterly Journal of Economic Growth and Development Research, 3(9), 70-59 (in Persian).

- Rahim Boroujerdi, Alireza (2003), A Theoretical and Operational Study on Currency Allocation through Establishing Currency Control, Journal of Commerce, 1, 128-168 (in Persian).

- Rasekhi S, Montazeri M (2016). The Impact of Macroeconomic Instability on Exchange Rate Pass Through: Some Evidence from Smooth Transition Regression (STR) Model. jemr, 6 (22) :7-31 (in Persian).

- Rasekhi Saeed, Montazeri Shortkali Mojtaba (2015), The Effect of Macroeconomic Instability on Currency Exchange Rate: Evidence from Mild Transition Regression (STR). Journal of Economic Modeling Research, 1 (1), 1-19 (in Persian).

- Snowden, B. and H. Wayne and P. Vinarkovic, (2004), The New Guide to Macroeconomics, Translated by Mansour Khalili Iraqi and Ali Souri, Tehran, Baradaran Publishing, First Edition (in persian).

- Teixeira, A. C, \& Fortuna, N. (2004). Human Capital, Trade and LongRun Productivity. Testing The Technological Absorption Hypothesis for The Portuguese Economy 1960- 2001, CEMPRE, Faculdade De Economic.

- Yousif FMK and Musa AMA (2018). The Determinants Factors of Balance of Payments: An Investigation from Sudan through the Period 1980-2016, Edelweiss Appli Sci Tech 2: 41-45. 


\title{
Evaluating the Impacts of Balance of Payments Variables Shock on Selected Macroeconomic Variables Using FAVAR
}

\author{
Morteza Chashti ${ }^{1}$; Mohammadreza Lotfalipour ${ }^{2}$; Behname Mehd ${ }^{3}$; \\ Ebrahimisalari Taghi ${ }^{4}$
}

Received: 2019/07/8 Accepted: 2019/12/16

\begin{abstract}
International balance of payments is one of the most common criteria for measuring the flow of trade and capital transfers in an open economy. The three main components of this balance are: trade balance, current account (or difference between export and import of goods and services) and capital account. In this study, factor augmented vector autoregressive model (FAVAR) was used to evaluate the effects of balance of payments shocks on macroeconomic variables in the Iran economy in periode 1989-2017. The factors used in this study included economic growth, oil revenues, money growth, inflation, exchange rates and interest rates. The results show that the shock from the current account and capital account led to an increase in production, consumption and investment. The reaction of nominal sector variables such as inflation and interest rate to positive shock was also positive. Comparison of the results of this study shows that incorporation of hidden variables and factors into the model resulted in faster response of macroeconomic variables to the shocks entered by the balance of payments components.
\end{abstract}

Keywords: Balance Payments, Current Account, Capital Account, Exchange Rate, Factor Augmented Vector Auto-Regressive Model (FAVAR).

JEL Classification: H53, E21, M52, C59.

1. PhD student in International Campus of Ferdowsi University of Mashhad Email:cmorteza33@gmail.com

2. Professor in Faculty of Administrative and Economic Sciences, Ferdowsi University of Mashhad (Corresponding Author) Email:lotfalipour@um.ac.ir

3. Professor in Faculty of Administrative and Economic Sciences, Ferdowsi University of Mashhad Email:mehdi_behnamei@um.ac.ir

4. Professor in Faculty of Administrative and Economic Sciences, Ferdowsi University of Mashhad Email:ebrahime@um.ac.ir 